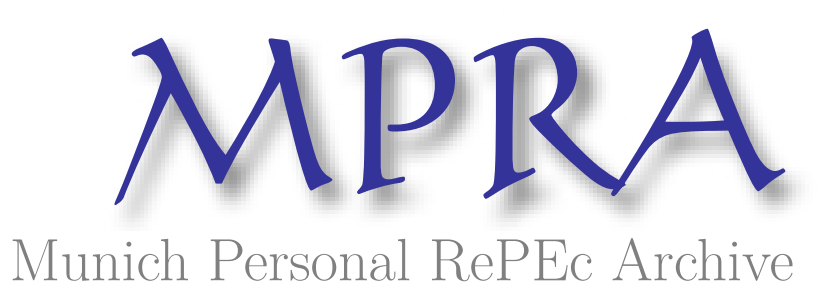

\title{
CPTPP: Implications for Malaysia's Merchandise Trade Balance
}

BANGA, RASHMI

UNCTAD

25 March 2019

Online at https://mpra.ub.uni-muenchen.de/93254/

MPRA Paper No. 93254, posted 18 Apr 2019 08:20 UTC 


\title{
CPTPP: Implications for Malaysia's Merchandise Trade Balance
}

\author{
Rashmi Banga*
}

\begin{abstract}
A mega regional Free Trade Agreement like the Comprehensive and Progressive Agreement for Trans-Pacific Partnership (CPTPP) has the potential to impact countries which are inside as well as those which are outside the agreement. This paper provides empirical estimates of potential changes in Malaysia's merchandise balance of trade if it joins the CPTPP and compares it to its trade balance if it does not join this free trade agreement (FTA). A positive balance of merchandise trade is important for Malaysia as it is a net importer of services. However, since 2010 Malaysia's merchandise imports have been growing much faster than its exports. Using SMART simulations, the estimates show that if Malaysia joins the CPTPP its imports will rise much more than its exports leading to a worsening of its trade balance by around US\$2.4 billion per annum. Imports of vehicles from the CPTPP countries will increase including that of plastics and its articles. Exports to the CPTPP partner countries will rise only marginally as Malaysia already has free trade agreements with its top three export destination countries, i.e., Japan, Singapore and Australia, which account for $84 \%$ of its exports to the CPTPP partner countries. Remaining out of the CPTPP will also adversely impact Malaysia's exports to the CPTPP countries but this decline is much smaller compared to the rise in its imports if it joins the CPTPP. The estimated tariff revenue loss to Malaysia of joining the CPTPP is estimated at US\$1.6 billion per annum. The paper argues that along with the traditional indicators of trade competitiveness like trade balance developing countries also need to give importance to preserving their policy space in free trade agreements as the fourth digital revolution is changing the ways products are manufactured and exported. Growing trade in electronic transmissions will be a game changer in the area of international trade competitiveness.
\end{abstract}

\section{Introduction}

Malaysia has always been a net exporter in its merchandise trade but a net importer of services. In 2017 , it enjoyed $\$ 22.6$ billion of merchandise trade surplus while its net services imports amounted to US\$ 5.3 billion $^{1}$. While Malaysia enjoys a positive trade balance in its merchandise trade, this trade balance has been steadily declining over the years. It declined from US\$34 billion in 2010 to US\$23 billion in 2015 and further to US\$22.6 billion in 2017. Most of its merchandise exports comprise of manufactured goods $(67 \%)$ and fuel $(15 \%)$ with top five export products going to Singapore, China and the USA. While Malaysia's exports have posted strong and resilient growth with an average annual growth rate of $4.4 \%$ in the period $2010-2017$, its imports have grown faster with an average annual

\footnotetext{
*Senior Economic Affairs Officer, Unit of Economic Cooperation and Integration among Developing Countries, Division on Globalization and Development Strategies, UNCTAD. Views expressed are personal

${ }^{1}$ Source: UNCTADSTAT
} 
growth rate of $6.6 \%$. Maintaining a positive merchandise trade surplus is important for Malaysia in the face of the faster growing imports as well as a negative trade balance in services, which declined from (+) US\$2.0 billion in 2010 to (-) US\$5.3 billion in 2017.

In this context, it becomes important to examine the implications of any new regional trade agreement like the Comprehensive and Progressive Agreement for Trans-Pacific Partnership (CPTPP) on Malaysia's merchandise exports and imports as well as its balance of trade. The share of 10 CPTPP partner countries in Malaysia's global exports has remained on an average around $31 \%$ in the period 2010- 2017, while their share in Malaysia's global imports has remained around 27\%.

The CPTPP, which followed the Trans-Pacific Partnership Agreement (TPP12) after the withdrawal of the USA, was signed by 11 participating countries - Australia, Brunei Darussalam, Canada, Chile, Japan, Malaysia, Mexico, New Zealand, Peru, Singapore and Viet Nam - on $8^{\text {th }}$ March 2018 in Santiago, Chile. By February 2019, seven out of the eleven countries had completed their ratification procedure. These are Mexico, Japan, Singapore, Australia, New Zealand, Canada and Viet Nam. Malaysia is in the process of re-examining the implications of the CPTPP. This paper estimates the likely impact of the CPTPP on Malaysia's merchandise exports, imports and its trade balance. The rest of the paper is organized as follows: section 2 briefly reviews the existing literature on the CPTPP; section 3 highlights the existing trends in Malaysia's trade with the CPTPP partner countries; section 4 discusses the methodology adopted to estimate the impact of the CPTPP on Malaysia's exports and imports to the СРTPP partner countries; section 5 presents the results at the country level as well as at the disaggregated product level; section 6 reports results of potential import tariff revenue loss to Malaysia of the CPTPP; section 7 concludes and provides a way forward.

\section{Existing Literature on CPTPP}

While there is an extensive literature on the impact of TPP on TPP12 countries, very limited studies exist which estimate the impact of CPTPP on the partner countries' trade. The exclusion of the USA from the TPP has drastically changed the results which were arrived at by the existing literature on TPP. The USA being the largest trading partners for all the TPP partner countries had the maximum weight in terms of bringing economic gains and losses to the TPP partner countries.

Very few studies exist which estimates the economic impact of the CPTPP. Some of the existing literature shows that the CPTPP without the USA cannot bring the expected trade gains for the CPTPP11 partner countries. For example, according to World Bank (2018), the CPTPP will increase Viet Nam's GDP by 1.1 per cent by 2030 but in terms of its trade balance, the exports are projected to grow by $4.2 \%$, and imports by $5.3 \%$, which will worsen Viet Nam's existing trade balance. PIIE (2017) compared the impact of the TPP and the CPTPP for the 11-member countries. While the study reports an expected rise in exports of these countries, especially for Malaysia and Viet Nam, it is silent about the expected rise in their imports. With USA out of this regional trade agreement, these countries have lost their biggest export market while retaining their import partners. 
Further the methodology adopted by the existing studies including that used by the PIIE (2017) has been strongly criticized in the economic literature. The computable general equilibrium (CGE) models that have been adopted are based on unreasonable assumptions such as full employment, which will always show positive gains in the gross domestic product (GDP) (Raza et al, 2014) ${ }^{2}$. According to Taylor and Arnim (2006), most of the CGE models assume (i) fixed or 'full' employment of labour and capital is maintained everywhere in the world (ii) each country's trade deficit (or surplus) stays constant after liberalization; and (iii) completely flexible taxes on households, which enable each country's internal economy to adjust smoothly. The assumption regarding the 'constant trade balance' implies that if government revenues change due to tariff reduction or other trade policies, government expenditures must adjust endogenously to satisfy the fixed budget deficit. However, in real world this is never the case. The assumption regarding completely flexible taxes on households, imply that "any changes in government budget are automatically compensated by income tax rates on households". These assumptions mean that the models are designed in such a way that 'the price system' will always respond to liberalization in a way which leads to increases in overall well-being. These assumptions are made in most of the studies assessing implications of the TPP and the CPTPP, including the PIIE studies $(2012,2017)$.

According to Panagariya and Duttagupta (2001), CGE models that show 'gains' for a country from its own preferential liberalization are able to do so only by using internally inconsistent assumptions. The 'Armington assumption' used in all CGE models, including Petri et al (2017), implies that there exists 'product differentiation' i.e., no country, howsoever small, produces something which is also produced by another country in the world. In other words, domestic and foreign products are imperfect substitutes. For example, it is assumed that oil produced in one country is different from the oil produced by any other country, and therefore it can never be completely substituted.

According to Raza et al (2014), the costs of 'regulatory changes' are also never estimated by CGE models. CPTPP involves considerable regulatory changes in the member countries which can have huge short-term adjustment costs, which are ignored by the CGE models.

This paper estimates the likely increase in merchandise imports and exports of Malaysia post CPTPP, estimating the per annum change in Malaysia's Balance of Trade following CPTPP. The methodology adopted is partial equilibrium analysis at a HS 6-digit product disaggregation and therefore avoids the above discussed restrictive assumptions.

\section{Existing Trends in Malaysia's Trade with CPTPP Members}

\footnotetext{
${ }^{2}$ Raza, W., Grumiller, J, Taylor, L., Tröster, B., von Arnim, R. (2014) 'Assess TTIP: Assessing the Claimed Benefits of the Transatlantic Trade and Investment Partnership'. Vienna: Austrian Foundation for Development Research
} 
Malaysia has enjoyed a net merchandise trade balance since 2009, however this trade balance has been steadily declining. It declined from USD 34 billion in 2009 which was $21 \%$ of its exports to USD 23 billion in 2017 which amounted to $10 \%$ of its exports (Figure1).

Figure 1: Malaysia's Merchandise Exports, Imports and Trade Balance (US\$ billion): 2009-2017

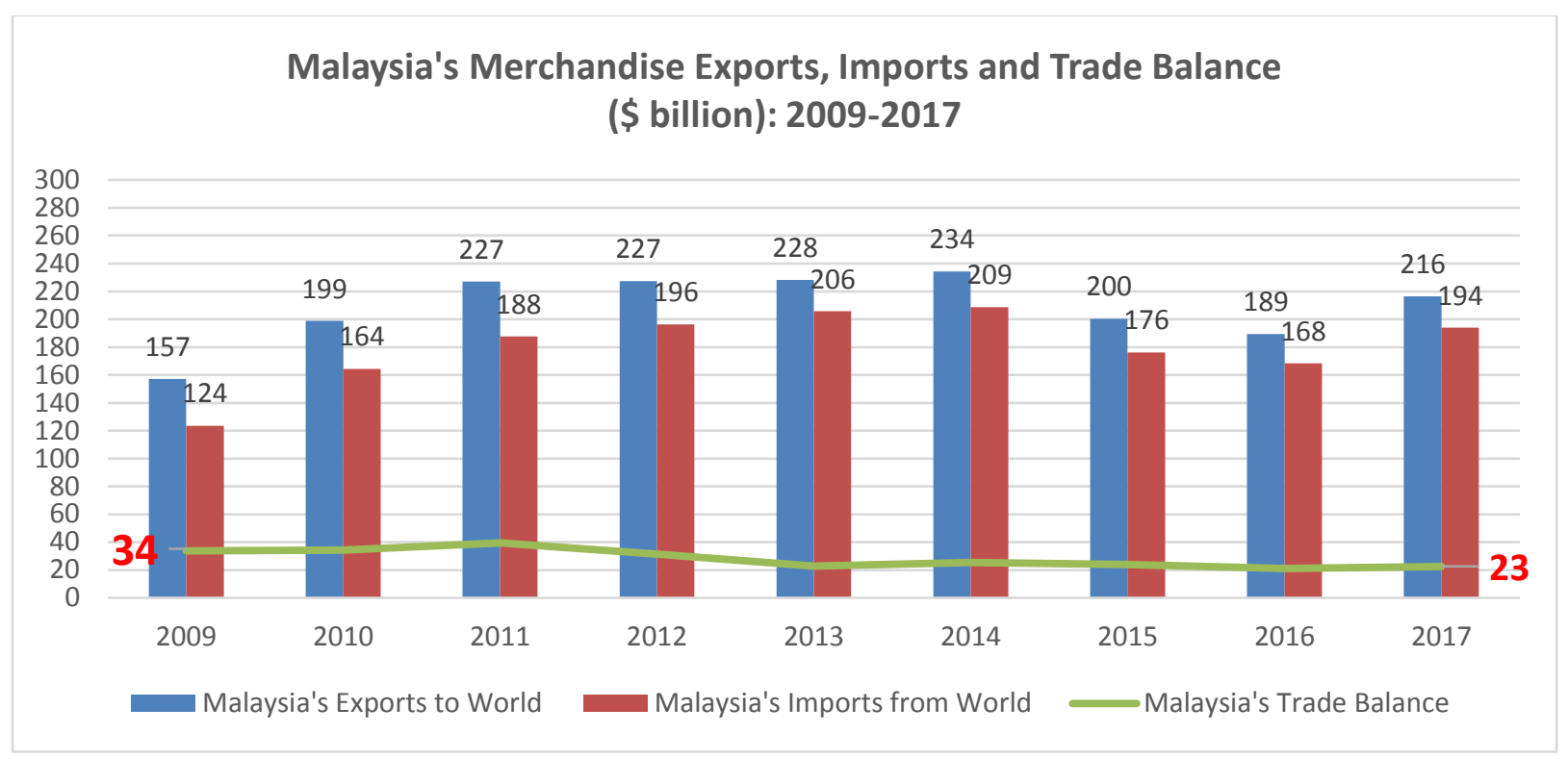

Source: World Integrated Trade Solutions, World Bank and UNCTAD

The share of CPTPP partner countries of Malaysia's global exports and imports has remained on an average around $32 \%$ and $27 \%$ respectively between 2010 to 2017 . Examining the share of different CPTPP countries in Malaysia's exports and imports, we find that within the CPTPP Singapore is the largest export market for Malaysia (46\%) followed by Japan (26\%) in terms of value of exports. It is important to note that with its two largest importers which account for $72 \%$ of Malaysia's exports to CPTPP partner countries, Malaysia already as FTAs. In terms of Malaysia's imports, share of Japan and Singapore account for around 74\% of Malaysia's total imports from CPTPP partner countries (Figure 2). Australia accounts for around 10\% of Malaysia's exports and imports to CPTPP. Australia also has an existing FTA with Malaysia. These are the three important countries for Malaysia within CPTPP, with whom Malaysia already has FTAs and therefore may not gain any additional tariff concessions by entering CPTPP. Canada, Mexico and New Zealand have minor share in Malaysia's merchandise trade.

Figure 2: Share of CPTPP Countries in Malaysia's Exports and Imports 


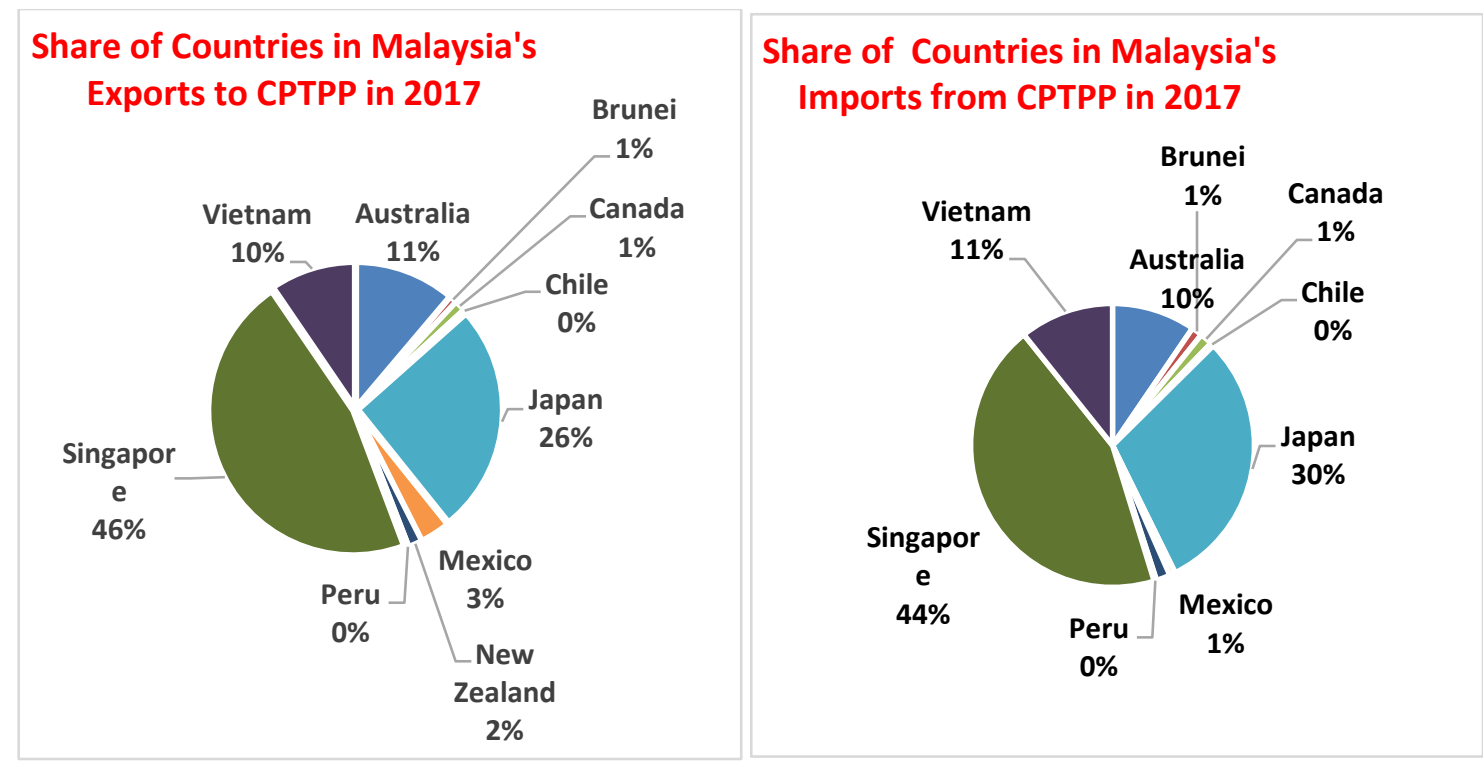

Source: World Integrated Trade Solutions, World Bank and UNCTAD

In terms of product-wise exports and imports, Appendix Table A.1 reports Malaysia's total exports and imports in different product categories (HS 2-Digit) to and from CPTPP countries and their share in Malaysia's global exports and imports in those product categories. The top five ranking products of exports of Malaysia in CPTPP countries are electrical machinery and equipment and parts thereof; mineral fuels, mineral oils and products of their distillation; machinery and mechanical appliances; plastics and articles thereof; optical, photographic, cinematographic products; and animal or vegetable fats and oils,

The top five products with highest share of CPTPP countries in Malaysia's global imports are wool, fine or coarse animal hair; horsehair yarn and woven fabric; nickel and articles thereof; dairy produce; birds' eggs; natural honey; edible products of animal origin, not elsewhere specified or included; cork and articles of cork; and live animals. CPTPP countries have more than $60 \%$ share in Malaysia's global imports in these products. In terms of Malaysia's exports to CPTPP countries the top five ranking products are clocks and watches and parts thereof; articles of stone, plaster, cement, asbestos, mica or similar materials; carpets and other textile floor coverings; cereals; and meat and edible meat offal apart from live animals. CPTPP countries have more than 64\% share in Malaysia's global exports in these products.

With respect to Malaysia's tariffs vis-a-vis CPTPP10 countries, given that Malaysia already has existing trade agreements with most of the countries, Malaysia's applied and Bound tariffs are on an average lower than compared its MFN tariffs. Table 1 reports Malaysia's average tariffs with respect to the CPTPP10 countries and CPTPP10 countries average tariffs vis-a-vis Malaysia. It is important to note that the tariff liberalization for Malaysia will be greater than the CPTPP10 countries as Malaysia's 
average tariffs are higher than their average tariffs for total trade. However, while average industrial tariffs are higher in Malaysia, agricultural tariffs are higher in CPTPP10 countries vis-a-vis Malaysia.

Table 1: Malaysia's Tariffs vis-à-vis CPTPP10 Countries in 2016

\begin{tabular}{|l|l|r|r|r|}
\hline \multicolumn{2}{|l|}{ Malaysia vis-à-vis CPTPP10 } & $\begin{array}{l}\text { WTO HS } \\
\text { Agricultural }\end{array}$ & \multicolumn{1}{l|}{$\begin{array}{l}\text { WTO HS } \\
\text { Industrial }\end{array}$} & Total Trade \\
\hline Applied Duties & Simple Average & 2.77 & 5.61 & $\mathbf{5 . 2 8}$ \\
\hline Applied Duties & Weighted Average & 3.7 & 4 & $\mathbf{3 . 5 1}$ \\
\hline Bound Duties & Simple Average & 11.54 & 15.24 & $\mathbf{1 4 . 7 5}$ \\
\hline Bound Duties & Weighted Average & 12.5 & 9.03 & $\mathbf{8 . 9}$ \\
\hline CPTPP10 vis-a-vis Malaysia & & & \\
\hline Applied Duties & Simple Average & 2.93 & 2.47 & $\mathbf{1 . 1 1}$ \\
\hline Applied Duties & Weighted Average & 4.45 & 1.59 & $\mathbf{0 . 2 3}$ \\
\hline Bound Duties & Simple Average & 14.19 & 14.48 & $\mathbf{1 3 . 9 4}$ \\
\hline Bound Duties & Weighted Average & 11.22 & 9.17 & $\mathbf{7 . 6 4}$ \\
\hline
\end{tabular}

Source: TRAINS database, World Integrated Trade Solutions, WITS

\section{Methodology Used to Estimate Impact of CPTPP on Malaysia's Trade Balance}

To estimate the impact of the CPTPP on Malaysia's trade balance, we use SMART simulations which are based on Partial equilibrium and available in World Integrated Trade Solutions-WITS (World Bank and UNCTAD) $)^{3}$. One of the advantages of this approach is that it allows estimation of tariff reduction at a very disaggregated level, for example, implications of removing tariffs on broken rice (at HS sixdigit disaggregation). HS-Combined nomenclature is used by SMART simulations. Such a disaggregated product-level estimations of tariff reductions are not possible in any other model. SMART simulations are appropriate to use for the CPTPP analysis as only few products have high tariffs in many of the member countries and implications for removing these tariffs on exports, imports, trade creation and trade diversion can be estimated. This also resolves a number of "aggregation biases." However, it needs to be remembered that this result of partial equilibrium analysis applies to only that product/sector and ignores inter-sectoral linkages. For estimating trends in Malaysia's trade HS2012 nomenclature has been used.

The analysis is undertaken to estimate the impact of $100 \%$ tariff liberalization for all the CPTPP countries. The results arrived for exports of Malaysia will be over-estimated as in the CPTPP while

${ }^{3}$ https://wits.worldbank.org/ 
Malaysia removes tariffs on $100 \%$ imports, Japan removes tariffs on $95 \%$ of imports and Canada and Viet Nam remove tariffs on $97 \%$ of imports while Mexico removes tariffs on $99 \%$ of imports ${ }^{4}$.

\section{Impact of CPTPP on Malaysia's Trade Balance: Results}

The impact of entering the CPTPP on Malaysia's imports, exports and trade balance is estimated using the above discussed methodology. The results are arrived at the country level as well as at the product level. The analysis also reports the results of new imports that will be created for Malaysia due to the CPTPP, i.e., 'trade creation' as well as imports that Malaysia will divert from non-CPTPP countries to instead buy from the CPTPP countries, i.e., 'trade diversion.' Impact of the CPTPP on Malaysia' exports is also estimated. Further, the impact of Malaysia not entering the CPTPP (while other 10 countries ratify the CPTPP) is estimated on Malaysia's exports and imports.

\subsection{Impact on Malaysia's Imports from CPTPP Countries}

Table 1 reports the results using the SMART simulations of the impact of CPTPP on Malaysia's trade. The simulation results show that if Malaysia enters CPTPP and all 11 countries bring their tariffs down to zero, Malaysia's total imports from the CPTPP partner countries will rise by US $\$ 2.5$ billion per annum. Maximum increase of imports will take place from Japan, in which case imports into Malaysia are estimated to increase by US $\$ 1.5$ billion (Table 2). This is followed by increase in imports from Singapore and Vietnam.

Table 2: Impact of the CPTPP on Malaysia's Imports from CPTPP Partner Countries

\begin{tabular}{|l|r|r|r|r|r|r|}
\hline & \multicolumn{1}{|c|}{$\begin{array}{c}\text { Imports in } \\
\mathbf{2 0 1 6} \\
\text { (US\$1000) }\end{array}$} & $\begin{array}{c}\text { Imports Post } \\
\text { CPTPP } \\
\text { (US\$1000) }\end{array}$ & $\begin{array}{c}\text { Change in } \\
\text { Imports post } \\
\text { CPTPP } \\
\text { (US\$1000) }\end{array}$ & $\begin{array}{c}\text { Trade } \\
\text { Creation } \\
\text { (US\$1000) }\end{array}$ & $\begin{array}{c}\text { Trade } \\
\text { Diversion } \\
\text { Effect in } \\
\text { (US\$1000) }\end{array}$ & $\begin{array}{c}\text { Percentage } \\
\text { Change in } \\
\text { Imports }\end{array}$ \\
\hline Australia & 3695967 & 3766828 & 70861 & 37497 & 33365 & 2 \\
\hline Brunei & 156307 & 159172 & 2865 & 1662 & 1203 & 2 \\
\hline Canada & 663154 & 679072 & 15918 & 7764 & 8154 & 2 \\
\hline Chile & 104351 & 107335 & 2984 & 2074 & 910 & 3 \\
\hline Japan & $\mathbf{1 3 6 3 8 7 1 2}$ & $\mathbf{1 5} \mathbf{1 4 9 8 4 7}$ & $\mathbf{1 5 1 1 \mathbf { 1 3 5 }}$ & $\mathbf{8 5 6 9 3 7}$ & $\mathbf{6 5 4 1 9 8}$ & $\mathbf{1 1}$ \\
\hline Mexico & 366806 & 380421 & 13615 & 6320 & 7296 & 4 \\
\hline New Zealand & 684386 & 708549 & 24163 & 14145 & 10019 & 4 \\
\hline Peru & 76386 & 76882 & 496 & 321 & 175 & 1 \\
\hline Singapore & 17254412 & 17830565 & 576153 & 306893 & 269261 & 3 \\
\hline Vietnam & 4509779 & 4834617 & 324838 & 166989 & 157849 & 7 \\
\hline Total & 41150259 & 43693289 & $\mathbf{2 5 4 3 0 3 0}$ & 1400601 & 1142428 & $\mathbf{6}$ \\
\hline
\end{tabular}

Source: Author's estimations based on SMART simulations, WITS

\footnotetext{
${ }^{4}$ Table 2 of Chapter 2 http://www.piie.com/publications/briefings/piieb16-1.pdf.
} 
The results at the disaggregated product-level show that if Malaysia enters CPTPP the top five products whose imports will rise the most are vehicles; plastics and articles thereof; machinery and mechanical appliances; electrical machinery and equipment; and iron and steel (Table 3). Appendix Table A.2 reports the change in imports of $97 \mathrm{HS}$ chapter (2-digit) following Malaysia's entry into CPTPP. Imports of vehicles which enter Malaysia with a custom duty will rise by $36 \%$ if these duties are brought down to zero. Table 4 presents more details of the increase in imports of motor cars, above US $\$ 2$ million. Highest rise in imports will be of motor cars with HS code- 870323(of a cylinder capacity exceeding $1,500 \mathrm{cc}$ but not exceeding 3,000 cc), followed by motor cars under HS code870324 (of a cylinder capacity exceeding 3,000 cc), mainly from Japan.

Table 3: Impact of CPTPP on Malaysia's Imports from CPTPP Partner Countries: ProductLevel

\begin{tabular}{|c|c|c|c|c|c|c|}
\hline & $\begin{array}{c}\text { HS } \\
\text { Chapter }\end{array}$ & & $\begin{array}{c}\text { Imports of } \\
\text { Malaysia } \\
\text { Before } \\
\text { CPTPP } \\
\text { (US\$1000) } \\
(\mathbf{2 0 1 6 )}\end{array}$ & $\begin{array}{c}\text { Estimated } \\
\text { Imports of } \\
\text { Malaysia } \\
\text { after } \\
\text { CPTPP } \\
(\mathrm{US} \$ 1000)\end{array}$ & $\begin{array}{l}\text { Change in } \\
\text { Imports } \\
\text { post } \\
\text { CPTPP } \\
\text { (US\$1000) }\end{array}$ & $\begin{array}{c}\text { Percentage } \\
\text { Change in } \\
\text { Imports of } \\
\text { Malaysia } \\
\text { post } \\
\text { CPTPP } \\
(\%)\end{array}$ \\
\hline 1 & 87 & $\begin{array}{l}\text { Vehicles Other Than Railway or Tramway } \\
\text { Rolling Stock, And Parts and Accessories } \\
\text { Thereof }\end{array}$ & 1794805 & 2436822 & 642017 & 36 \\
\hline 2 & 39 & Plastics and Articles There of & 1325380 & 1562165 & 236785 & 18 \\
\hline 3 & 84 & $\begin{array}{l}\text { Nuclear Reactors, Boilers, Machinery and } \\
\text { Mechanical Appliances; Parts Thereof }\end{array}$ & 1353111 & 1585407 & 232296 & 17 \\
\hline 4 & 85 & $\begin{array}{l}\text { Electrical Machinery and Equipment and Parts } \\
\text { Thereof; Sound Recorders and Reproducers, } \\
\text { Television Image and Sound Recorders and } \\
\text { Reproducers, and Parts and Accessories of Such } \\
\text { Articles }\end{array}$ & 994438 & 1180381 & 185943 & 19 \\
\hline 5 & 72 & Iron and Steel & 918529 & 1097007 & 178478 & 19 \\
\hline 6 & 76 & Aluminium and Articles There of & 260588 & 373546 & 112958 & 43 \\
\hline 7 & 71 & $\begin{array}{l}\text { Natural or Cultured Pearls, Precious or Semi- } \\
\text { Precious Stones, Precious Metals, Metals Clad } \\
\text { With Precious Metal, And Articles Thereof; } \\
\text { Imitation Jewellery; Coin }\end{array}$ & 443476 & 539632 & 96156 & 22 \\
\hline 8 & 40 & Rubber and Articles Thereof & 328741 & 424852 & 96111 & 29 \\
\hline 9 & 73 & Articles of Iron or Steel & 657981 & 749545 & 91564 & 14 \\
\hline 10 & 48 & $\begin{array}{l}\text { Paper and Paperboard; Articles of Paper Pulp, } \\
\text { of Paper or of Paperboard }\end{array}$ & 309558 & 385994 & 76437 & 25 \\
\hline
\end{tabular}

Source: Author's estimations based on SMART simulations, WITS 
Table 4: Rise in Imports of Motor Cars in Malaysia post CPTPP post CPTPP

\begin{tabular}{|c|c|c|c|c|c|c|c|}
\hline $\begin{array}{l}\text { Product } \\
\text { Code at } \\
\text { 4digit }\end{array}$ & Product At 4digit & $\begin{array}{c}\text { Product } \\
\text { code At } \\
\text { 6digit }\end{array}$ & $\begin{array}{l}\text { Description of } \\
\text { Product At } \\
\text { 6digit }\end{array}$ & $\begin{array}{l}\text { Imports } \\
\text { from }\end{array}$ & $\begin{array}{l}\text { Malaysia's } \\
\text { Imports } \\
\text { Before the } \\
\text { CPTPP } \\
\text { (US\$1000) }\end{array}$ & $\begin{array}{l}\text { Malaysia's } \\
\text { Imports } \\
\text { after the } \\
\text { CPTPP } \\
\text { (US\$1000) }\end{array}$ & $\begin{array}{l}\text { Change in } \\
\text { Imports Post } \\
\text { the CPTPP } \\
\text { (US } \$ 1000)\end{array}$ \\
\hline 8703 & $\begin{array}{l}\text { Motor cars and other motor } \\
\text { vehicles principally } \\
\text { designed for the transport of } \\
\text { persons (other than those of } \\
\text { heading } 87.02 \text { ), including } \\
\text { station wagons and racing } \\
\text { cars. }\end{array}$ & 870323 & $\begin{array}{l}\text { Of a cylinder } \\
\text { capacity } \\
\text { exceeding } \\
1,500 \mathrm{cc} \text { but not } \\
\text { exceeding } \\
3,000 \mathrm{cc}\end{array}$ & Japan & 616972 & 821141 & 204170 \\
\hline 8703 & $\begin{array}{l}\text { Motor cars and other motor } \\
\text { vehicles principally } \\
\text { designed for the transport of } \\
\text { persons (other than those of } \\
\text { heading } 87.02 \text { ), including } \\
\text { station wagons and racing } \\
\text { cars. }\end{array}$ & 870324 & $\begin{array}{l}\text { Of a cylinder } \\
\text { capacity } \\
\text { exceeding } \\
3,000 \mathrm{cc}\end{array}$ & Japan & 85992 & 128169 & 42177 \\
\hline 8703 & $\begin{array}{l}\text { Motor cars and other motor } \\
\text { vehicles principally } \\
\text { designed for the transport of } \\
\text { persons (other than those of } \\
\text { heading } 87.02 \text { ), including } \\
\text { station wagons and racing } \\
\text { cars. }\end{array}$ & 870322 & $\begin{array}{l}\text { Of a cylinder } \\
\text { capacity } \\
\text { exceeding } \\
1,000 \mathrm{cc} \text { but not } \\
\text { exceeding } \\
1,500 \mathrm{cc}\end{array}$ & Japan & 37826 & 52801 & 14974 \\
\hline 8703 & $\begin{array}{l}\text { Motor cars and other motor } \\
\text { vehicles principally } \\
\text { designed for the transport of } \\
\text { persons (other than those of } \\
\text { heading } 87.02 \text { ), including } \\
\text { station wagons and racing } \\
\text { cars. }\end{array}$ & 870332 & $\begin{array}{l}\text { Of a cylinder } \\
\text { capacity } \\
\text { exceeding } \\
1,500 \mathrm{cc} \text { but not } \\
\text { exceeding } \\
2,500 \mathrm{cc}\end{array}$ & Japan & 15497 & 28676 & 13179 \\
\hline 8703 & $\begin{array}{l}\text { Motor cars and other motor } \\
\text { vehicles principally } \\
\text { designed for the transport of } \\
\text { persons (other than those of } \\
\text { heading } 87.02 \text { ), including } \\
\text { station wagons and racing } \\
\text { cars. }\end{array}$ & 870333 & $\begin{array}{l}\text { Of a cylinder } \\
\text { capacity } \\
\text { exceeding } \\
2,500 \mathrm{cc}\end{array}$ & Japan & 4933 & 6852 & 1919 \\
\hline
\end{tabular}

Source: Author's estimations based on SMART simulations, WITS

It is interesting to note that the CPTPP may lead to higher imports of plastic waste and scarp under plastics and plastic products. This import can increase by around 35\%, mainly coming from Japan, Singapore and Australia (Table 5). 
Table 5: Increase in Imports of Plastic Waste and Scrap post CPTPP in Malaysia

\begin{tabular}{|c|c|c|c|c|c|c|}
\hline $\begin{array}{l}\text { Product } \\
\text { Code at } \\
\text { 4digit }\end{array}$ & Product description at 4digit & $\begin{array}{l}\text { Imports } \\
\text { from } \\
\text { country }\end{array}$ & $\begin{array}{c}\text { Malaysia's } \\
\text { Imports } \\
\text { before the } \\
\text { CPTPP } \\
\text { (US } \$ 1000 \text { ) } \\
\text { in } 2016\end{array}$ & $\begin{array}{l}\text { Malaysia's } \\
\text { Estimated } \\
\text { Imports } \\
\text { after the } \\
\text { CPTPP } \\
\text { (US\$1000) } \\
\text { in 2016 } \\
\end{array}$ & $\begin{array}{c}\text { Change in } \\
\text { Imports } \\
\text { post } \\
\text { CPTPP } \\
\text { (US } \$ 1000) \\
\text { In } 2016\end{array}$ & $\begin{array}{c}\text { Percentage } \\
\text { Change in } \\
\text { Imports } \\
\text { Post } \\
\text { CPTPP } \\
(\%)\end{array}$ \\
\hline 3915 & $\begin{array}{l}\text { Waste, parings and scrap, of } \\
\text { plastics. }\end{array}$ & Japan & 8969 & 11991 & 3022 & 34 \\
\hline 3916 & $\begin{array}{l}\text { Waste, parings and scrap, of } \\
\text { plastics. }\end{array}$ & Singapore & 3284 & 4454 & 1169 & 36 \\
\hline 3917 & $\begin{array}{l}\text { Waste, parings and scrap, of } \\
\text { plastics. }\end{array}$ & Australia & 2184 & 2971 & 787 & 36 \\
\hline 3918 & $\begin{array}{l}\text { Waste, parings and scrap, of } \\
\text { plastics. }\end{array}$ & Canada & 1028 & 1430 & 401 & 39 \\
\hline 3919 & $\begin{array}{l}\text { Waste, parings and scrap, of } \\
\text { plastics. }\end{array}$ & Mexico & 413 & 570 & 158 & 38 \\
\hline 3920 & $\begin{array}{l}\text { Waste, parings and scrap, of } \\
\text { plastics. }\end{array}$ & $\begin{array}{l}\text { New } \\
\text { Zealand }\end{array}$ & 328 & 459 & 131 & 40 \\
\hline 3921 & $\begin{array}{l}\text { Waste, parings and scrap, of } \\
\text { plastics. }\end{array}$ & Vietnam & 37 & 51 & 14 & 38 \\
\hline 3922 & $\begin{array}{l}\text { Waste, parings and scrap, of } \\
\text { plastics. }\end{array}$ & Chile & 17 & 21 & 5 & 30 \\
\hline \multirow[t]{2}{*}{3923} & $\begin{array}{l}\text { Waste, parings and scrap, of } \\
\text { plastics. }\end{array}$ & Brunei & 3 & 4 & 1 & 30 \\
\hline & Total & & 16263 & 21951 & 5688 & 35 \\
\hline
\end{tabular}

Source: Author's estimations based on SMART simulations, WITS

\subsection{Change in Malaysia's Exports Post CPTPP}

While CPTPP may lead to a rise of US $\$ 2.5$ billion in Malaysia's imports, the CPTPP may not offer the opportunity to Malaysia to increase its exports substantially. There are two reasons for this. Firstly, Malaysia already has existing free trade agreements with its major trading partners within the CPTPP, i.e., Japan, Singapore and Australia. The existing tariffs are already very low in these countries, visa-vis Malaysia so any further trade agreements will not boost the exports of Malaysia substantially. However, within these trade agreements Malaysia has a sensitive list whereby Malaysia's tariffs are not very low vis-a-vis these countries. Any new trade agreement may imply lowering tariffs of sensitive products of Malaysia and consequently rise in its imports of these products like vehicles and plastics.

Table 6 reports the estimated rise in Malaysia's exports post CPTPP, which is only $0.2 \%$ of its existing imports in 2016. Highest rise in absolute terms is expected in Malaysia's exports to Vietnam followed by Canada. While Vietnam is part of ASEAN FTA along with Malaysia, it may have reserved high tariffs in some of the product lines of interest to Malaysia. The CPTPP could therefore lead to a rise in 
Malaysia's exports to Vietnam. Malaysia does not have an FTA with Canada and therefore there exists a potential for Malaysia to increase its exports to Canada post CPTPP. Appendix Table A.3 reports the product-wise and country-wise likely increase in exports of Malaysia (greater than US\$ 1million) if it ratifies the CPTPP.

Table 6: Estimated Change in Malaysia's Exports post CPTPP

\begin{tabular}{|l|r|r|r|r|}
\hline & $\begin{array}{l}\text { Exports Before } \\
\text { CPTPP (US\$1000) }\end{array}$ & $\begin{array}{l}\text { Exports After } \\
\text { CPTPP } \\
\text { (US\$1000) }\end{array}$ & $\begin{array}{l}\text { Change in Exports } \\
\text { post CPTPP } \\
\text { (US\$1000) }\end{array}$ & $\begin{array}{l}\text { Percentage } \\
\text { Change in } \\
\text { Exports } \\
(\boldsymbol{\%})\end{array}$ \\
\hline Australia & 6445327 & 6406655 & -38672 & -0.6 \\
\hline Brunei & 512029 & 510493 & -1536 & -0.3 \\
\hline Canada & 704494 & 722811 & 18317 & $\mathbf{2 . 6}$ \\
\hline Chile & 164104 & 175427 & 11323 & 6.9 \\
\hline Japan & 15250309 & 15250309 & 0 & 0 \\
\hline Mexico & 1890946 & 1898510 & 7564 & 0.4 \\
\hline New & 731767 & 731035 & -732 & -0.1 \\
Zealand & 122405 & 129260 & 6855 & 5.6 \\
\hline Peru & 27581069 & 27581069 & 0 & 0 \\
\hline Singapore & 5730266 & 5856332 & 126066 & $\mathbf{2 . 2}$ \\
\hline Vietnam & 59132717 & 59261902 & 129185 & 0.2 \\
\hline Total & & & & 0.2 \\
\hline
\end{tabular}

Source: Author's estimations based on SMART simulations, WITS

Note: It should be noted that the export figures of Malaysia to CPTPP countries do not match with the import figures of CPTPP countries from Malaysia. One reason is imports figures include c.i.f. But in come cases like Malaysia's exports to Mexico and Mexico's imports from Malaysia has huge difference. Some studies account this difference to misinvoicing. https://wits.worldbank.org/wits/wits/witshelp/content/data_retrieval/T/Intro/B2.Imports_Exports_and_Mirror.htm

The results show that there will be a fall in exports from Malaysia to Australia post the CPTPP. Although this may appear counter-intuitive, this is very likely within a regional trading bloc. Any regional free trade agreement leads to a shift in the regional pattern of trade with imports into partner countries being shifted from less competitive to more competitive countries within the region. This is 'trade diversion' which always accompanies trade creation within the free trade area. In case of Australia, post CPTPP it is estimated that there will be trade diversion for Australia and it will source more imports from other competitive countries as compared to Malaysia, adversely impacting Malaysia's exports to Australia.

Table 7 reports results of trade creation and trade diversion for Australia post CPTPP. The results indicate that Australia's imports from Malaysia declines while they increase from Japan by $7 \%$. There will be no new exports to Australia from Brunei, Chile, Malaysia, New Zealand and Singapore. Japan on the other hand will have new exports to Australia of US\$ 711 million along with trade diversion of US\$ 228 million. 
Table 7: Australia's Trade Diversion from Malaysia post CPTPP

\begin{tabular}{|c|c|c|c|c|c|}
\hline & $\begin{array}{c}\text { Imports of } \\
\text { Australia from } \\
\text { Countries in } 2016 \\
\text { (US\$1000) }\end{array}$ & $\begin{array}{c}\text { Trade Creation } \\
\text { Effect post } \\
\text { CPTPP } \\
\text { (US\$1000) }\end{array}$ & $\begin{array}{c}\text { Trade Diversion } \\
\text { Effect post } \\
\text { CPTPP } \\
\text { (US\$1000) }\end{array}$ & $\begin{array}{c}\text { Trade Total } \\
\text { Effect post } \\
\text { CPTPP } \\
\text { (US\$1000) }\end{array}$ & $\begin{array}{c}\text { Percentage } \\
\text { Change in } \\
\text { Imports post } \\
\text { CPTPP }\end{array}$ \\
\hline Brunei & 229225 & 0 & -10 & -9 & 0 \\
\hline Canada & 1558291 & 31102 & 10753 & 41855 & 3 \\
\hline Chile & 397413 & 0 & -1764 & -1764 & 0 \\
\hline Japan & 14391496 & 711581 & 228517 & 940098 & $7 \%$ \\
\hline Malaysia & 6834028 & $\mathbf{0}$ & -38780 & -38780 & -1 \\
\hline Mexico & 1866294 & 32429 & 24806 & 57236 & 3 \\
\hline New Zealand & 5593377 & 0 & -54395 & -54395 & -1 \\
\hline Peru & 262864 & 852 & 780 & 1632 & 1 \\
\hline Singapore & 5117498 & 0 & -20966 & -20966 & 0 \\
\hline Vietnam & 3313112 & 6435 & -21321 & -14886 & 0 \\
\hline Total & 39563598 & 782399 & 127621 & 910020 & 2 \\
\hline
\end{tabular}

Source: Author's estimations based on SMART simulations, WITS

\section{3: Implications of CPTPP on Malaysia's Merchandise Trade Balance}

The simulations results reported in Table 8 present the results for the likely impact of CPTPP on Malaysia's merchandise trade balance. The results show that post CPTPP Malaysia's trade balance can worsen, falling from US $\$ 17.9$ billion in 2016 to US $\$ 15.5$ billion post CPTPP, i.e., a fall of around $13 \%$ in Malaysia's merchandise Balance of Trade is expected post CPTPP, if Malaysia joins the regional trade agreement.

Table 8: Impact of CPTPP on Malaysia's Merchandise Trade Balance

\begin{tabular}{|l|r|r|r|r|r|r|r|}
\hline & $\begin{array}{c}\text { Malaysia's } \\
\text { Imports in } \\
\mathbf{2 0 1 6} \\
\text { (US\$1000) }\end{array}$ & $\begin{array}{c}\text { Malaysia's } \\
\text { Exports in } \\
\mathbf{2 0 1 6} \\
\text { (US\$1000) }\end{array}$ & $\begin{array}{c}\text { Malaysia's } \\
\text { Trade Balance } \\
\text { in 2016 } \\
\text { (US\$1000) }\end{array}$ & $\begin{array}{c}\text { Estimated } \\
\text { Imports post } \\
\text { CPTPP } \\
\text { (US\$1000) }\end{array}$ & $\begin{array}{c}\text { Estimated } \\
\text { Exports Post } \\
\text { CPTPP } \\
\text { (US\$1000) }\end{array}$ & $\begin{array}{c}\text { Trade } \\
\text { Balance Post } \\
\text { CPTPP } \\
\text { (US\$1000) }\end{array}$ & $\begin{array}{c}\text { Change in } \\
\text { BOT } \\
\text { (US\$1000) }\end{array}$ \\
\hline Australia & 3695967 & 6445327 & 2749360 & 3766828 & 6408753 & 2641925 & -107435 \\
\hline Brunei & 156307 & 512029 & 355722 & 159172 & 510687 & 351515 & -4207 \\
\hline Canada & 663154 & 704494 & 41340 & 679072 & 722970 & 43898 & 2558 \\
\hline Chile & 104351 & 164104 & 59753 & 107335 & 175423 & 68088 & 8335 \\
\hline Japan & 13638712 & 15250309 & 1611597 & 15149847 & 15255611 & 105764 & -1505833 \\
\hline Mexico & 366806 & 1890946 & 1524140 & 380421 & 1899336 & 1518915 & -5225 \\
\hline New Zealand & 684386 & 731767 & 47381 & 708549 & 731020 & 22471 & -24910 \\
\hline Peru & 76386 & 122405 & 46019 & 76882 & 129299 & 52417 & 6398 \\
\hline Singapore & 17254412 & 27581069 & 10326657 & 17830565 & 27581069 & 9750504 & -576153 \\
\hline Vietnam & 4509779 & $\mathbf{5 7 3 0 2 6 6}$ & 1220487 & 4834617 & 5856024 & 1021407 & -199080 \\
\hline Total & $\mathbf{4 1 \mathbf { 1 5 0 2 5 9 }}$ & $\mathbf{5 9 1 3 2 ~ 7 1 7}$ & $\mathbf{1 7 9 8 2 ~ 4 5 8}$ & $\mathbf{4 3 6 9 3 ~ 2 8 9}$ & $\mathbf{5 9 2 7 0 ~ 1 9 3}$ & $\mathbf{1 5 5 7 6 9 0 4}$ & $\mathbf{- 2 ~ 4 0 5 ~ 5 5 2}$ \\
\hline
\end{tabular}

Source: Author's estimations based on SMART simulations, WITS 


\section{4: Implications of CPTPP on Malaysia's Balance of Trade if Malaysia does not join CPTPP}

It is often argued that a country which stays out of a regional trade agreement loses in terms of its exports as tariffs of the partner countries within the FTA are lower with respect to each-other compared to countries outside the FTA. This would imply a trade diversion away from countries out of the agreement and towards countries within the trade agreement, adversely impacting the exports of excluded countries.

However, the extent of trade diversion depends on whether the excluded country has an existing free trade agreement with its major trading partners, which are participating in the regional FTA. In case of Malaysia, it is found that Malaysia already has existing FTAs with Singapore, Japan and Australia. These three countries account for around $82 \%$ and $84 \%$ of Malaysia's exports and imports within CPTPP. Consequently, Malaysia may not lose much in terms of trade diversion by staying out of CPTPP.

Table 9 reports the estimated results, which show that if Malaysia decides not to join CPTPP, the loss of exports from Malaysia following the CPTPP will be only $0.09 \%$ of its existing exports to the CPTPP partner countries, which amounts to US\$53.2 million.

Table 9: Impact of CPTPP on Malaysia's Exports if Malaysia does not join CPTPP

\begin{tabular}{|l|r|r|r|r|}
\hline & $\begin{array}{c}\text { Exports of Malaysia } \\
\text { before CPTPP in } \\
\mathbf{2 0 1 6} \text { (US\$1000) }\end{array}$ & $\begin{array}{c}\text { Exports of Malaysia } \\
\text { post CPTPP } \\
\text { (US\$1000) }\end{array}$ & $\begin{array}{c}\text { Change in Exports } \\
\text { of Malaysia post } \\
\text { CPTPP (US\$1000) }\end{array}$ & $\begin{array}{c}\text { Percentage Loss in } \\
\text { Exports of Malaysia } \\
\text { post CPTPP if } \\
\text { Malaysia does not join } \\
\text { CPTPP }\end{array}$ \\
\hline Australia & 6445327 & 6436304 & -9023 & -0.14 \\
\hline Brunei & 512029 & 512029 & 0 & 0 \\
\hline Canada & 704494 & 703156 & -1339 & -0.19 \\
\hline Chile & 164104 & 162250 & -1854 & -1.13 \\
\hline Japan & 15250309 & 15233534 & -16775 & -0.11 \\
\hline Mexico & 1890946 & 1889622 & -1323 & -0.21 \\
\hline New & 731767 & 730230 & -85 & -0.07 \\
Zealand & 122405 & 122319 & 0 & 0 \\
\hline Peru & 27581069 & 27581069 & -33809 & -0.59 \\
\hline Singapore & 5730266 & 5696458 & $\mathbf{- 5 3 2 1 9}$ & $\mathbf{- 0 . 0 9}$ \\
\hline Vietnam & $\mathbf{5 9 1 3 2 7 1 7}$ & 59079498 & & \\
\hline Total & & & -137 \\
\hline
\end{tabular}

Source: Author's estimations based on SMART simulations, WITS 
While Malaysia's exports to CPTPP partner countries will be adversely impacted marginally if it does not join CPTPP, with no changes to its tariffs, the imports will not change leading to a lower but a healthier trade balance than if it joins the CPTPP of US \$ 17.92 billion (Table 10).

Table 10: Comparison of Change in Malaysia's Trade Balance with CPTPP and without CPTPP

\begin{tabular}{|l|r|r|r|}
\hline & $\begin{array}{c}\text { Malaysia's Trade } \\
\text { Balance in 2016 } \\
\text { (US\$1000) }\end{array}$ & $\begin{array}{c}\text { Trade Balance Post } \\
\text { CPTPP If Malaysia } \\
\text { Joins CPTPP } \\
\text { (US\$1000) }\end{array}$ & $\begin{array}{c}\text { Trade Balance Post } \\
\text { CPTPP If Malaysia } \\
\text { does not Join CPTPP } \\
\text { (US\$1000) }\end{array}$ \\
\hline Australia & 2749360 & 2639827 & 2740337 \\
\hline Brunei & 355722 & 351321 & 355722 \\
\hline Canada & 41340 & 43739 & 40002 \\
\hline Chile & 59753 & 68092 & 57899 \\
\hline Japan & 1611597 & 100462 & 1594822 \\
\hline Mexico & 1524140 & 1518089 & 45844 \\
\hline New Zealand & 47381 & 22486 & 45933 \\
\hline Peru & 46019 & 52378 & 10326657 \\
\hline Singapore & 10326657 & 9750504 & 1186679 \\
\hline Vietnam & 1220487 & 1021715 & $\mathbf{1 7 9 2 9 2 3 9}$ \\
\hline Total & $\mathbf{1 7 9 8 2 4 5 7}$ & $\mathbf{1 5 5 6 8 6 1 4}$ & 1526 \\
\hline
\end{tabular}

Source: Author's estimations based on SMART simulations, WITS

\section{Potential Tariff Revenue Loss to Malaysia of joining CPTPP}

As discussed in section 3, on average Malaysia has higher import tariffs as compared to the other CPTPP countries. This implies that the tariff revenue loss to Malaysia will also be higher. Using the WITS simulation, the import tariff revenue loss of Malaysia is estimated. The results are reported in Appendix Table A.4. The total import tariff revenue loss to Malaysia by entering the CPTPP will be of around US $\$ 1.6$ billion per year, of which $26 \%$ of tariff revenue loss will be from removing custom duties on vehicles followed by plastics and articles thereof and machinery and mechanical appliances (Table 11). 
Table 11: Potential Tariff Revenue Loss to Malaysia if it ratifies the CPTPP

\begin{tabular}{|l|r|l|r|r|}
\hline S.No & HS & & $\begin{array}{l}\text { Total Tariff Revenue } \\
\text { Loss (US\$1000) }\end{array}$ & $\begin{array}{l}\text { \% of Total } \\
\text { Tariff } \\
\text { Revenue } \\
\text { Loss }\end{array}$ \\
\hline 1 & 87 & $\begin{array}{l}\text { Total } \\
\text { parts and accessories thereof }\end{array}$ & $\mathbf{- 1 6 4 3 0 0 3}$ & 26 \\
\hline 2 & 39 & plastics and articles thereof & -422413 & 9 \\
\hline 3 & 84 & $\begin{array}{l}\text { nuclear reactors, boilers, machinery and mechanical } \\
\text { appliances; parts thereof }\end{array}$ & -150164 & 8 \\
\hline 4 & 72 & iron and steel & -132047 & 7 \\
\hline 5 & 85 & $\begin{array}{l}\text { electrical machinery and equipment and parts thereof; } \\
\text { sound recorders and reproducers, television image and } \\
\text { sound recorders and reproducers, and parts and } \\
\text { accessories of such articles }\end{array}$ & -122065 & \\
\hline 6 & 40 & rubber and articles thereof & -113961 & \\
\hline 7 & 76 & aluminium and articles thereof & -82654 & \\
\hline 8 & 73 & articles of iron or steel & -79676 & \\
\hline 9 & 10 & Cereals & -68868 & \\
\hline 10 & 48 & paper and paperboard; articles of paper pulp, of paper or \\
of paperboard & -49474 & \\
\hline
\end{tabular}

Source: Author's estimations based on SMART simulations, WITS

\section{Conclusion and the Way Forward}

In the scenario of a growing number of bilateral and regional free trade agreements, mega regional trade agreements like the CPTPP pose new challenges for the developing countries. Not only do these agreements stretch trade liberalization beyond the existing limits, they take away important policy space of the governments for regulating their imports to protect their domestic industry and to promote their exports in order to generate employment. Custom duties are an important policy tool in the hands of the governments which not only generate revenue but also leverage domestic production and employment. In this context, this paper estimates the impact of the CPTPP and associated full trade liberalization on Malaysia's merchandise balance of trade.

Using SMART simulations, the results show that if Malaysia enters the CPTPP it will experience a surge in its imports amounting to around US $\$ 2.5$ billion, i.e., a $6 \%$ rise in its imports while its exports rise only marginally by around $0.2 \%$ from CPTPP countries. The reason for this being that Malaysia already has existing FTAs with its major export markets in the CPTPP namely Japan, Singapore and Australia which together account for $84 \%$ of Malaysia's exports to CPTPP. The associated trade balance of Malaysia will fall by US $\$ 2.4$ billion if Malaysia ratifies the CPTPP, which is $13 \%$ of its 
existing trade balance. If Malaysia does not ratify the CPTPP, Malaysia's trade balance will fall marginally by $0.2 \%$ (US $\$ 53$ million).

More importantly, remaining out of the CPTPP not only has a lower adverse impact on Malaysia' trade balance, it also provides the much-needed policy space to Malaysia for designing its industrial and trade policies. With the advent of the digital industrial revolution developing countries are fast losing their trade competitiveness, even in their traditional export sectors. The rising digital divide is providing a competitive edge to developed countries as they are steadily increasing the digital content in all stages of their manufacturing production. For example, Big data analytics along with artificial intelligence is being used in the pre-production stage; robotics and 3D printing in the production stage and e-commerce and internet of things in the post production stage.

The rising use of digital technologies and increasing product digitalization require developing countries to re-think their existing industrial and trade policies with the objective of increasing their trade competitiveness through higher use of digital technologies and digital services ${ }^{5}$. The CPTPP chapters have some binding commitments especially in the area of zero customs duties on electronic transmissions which has the potential of eroding all the negotiated industrial tariffs in the trade agreements whether at the regional level or at the $\mathrm{WTO}^{6}$. The growing trade in electronic transmissions implies that the core resources of digital industrial revolution namely data, software and computeraided design files (CAD files) used in 3D printing are increasingly being electronically transmitted. This may provide higher market access to the foreign suppliers in the developing countries as they will be able to manufacture products within the national boundaries of the developing counties without their physical presence. They can electronically transmit the software and CAD files and 3D print the currently manufactured products. While 3D printing is still considered to be catering to the niche markets, its market has grown annually by $22 \%$ in the period $2014-2018^{7}$. It is estimated that if current growth of investments in 3D printing continues, $50 \%$ of the manufactured goods will be 'printed' in 2060 and if investments in 3D printing doubles, this target will be achieved in 2040 (ING, 2017) ${ }^{8}$. This will wipe out almost $40 \%$ of cross-border physical global trade. The fourth digital industrial revolution is fast changing the landscape of international trade. While traditional indicators of trade competitiveness like balance of trade are still important inputs into the policy making of developing countries, there is a need to go beyond raising the trade balance to preserving policy space for regulating trade in the digital world.

\footnotetext{
${ }^{5}$ Banga (2018)

${ }^{6}$ For detailed discussion on this see Banga (2019)

$7 \quad$ Statista (https://www.statista.com/statistics/796237/worldwide-forecast-growth-3d-printing-market/)

${ }^{8}$ ING (2017), “3D printing: a threat to global trade” https://www.ing.nl/media/ING_EBZ_3d-printing_tcm162131996.pdf
} 


\section{References}

Banga Rashmi (2014). Trans Pacific Partnership Agreement (TPPA): Implications for Domestic Value Added Trade of Malaysia. background paper, no. RVC-12, UNCTAD.

Banga Rashmi. (2017). Rising Product Digitalization and Losing Trade Competitiveness. UNCTAD/GDS/ECIDC/2017/3, UNCTAD, Geneva.

Banga Rashmi. (2019). Growing Trade in Electronic Transmissions: Implications for the South. UNCTAD Research Paper No. 29 UNCTAD/SER.RP/2019/1, UNCTAD.

Panagariya, A. and Duttagupta (2001). The 'Gains' from Preferential Trade Liberalization in the CGEs: Where Do They Come From? in S. Lahiri, ed. Regionalism and Globalization: Theory and Practice, Routledge. London, 39-60.

Peter A. Petri, Michael G. Plummer, Shujiro Urata and Fan Zhai, (October 2017). Going It Alone in the Asia-Pacific: Regional Trade Agreements Without the United States. Working Paper, PIIE, pp 17-10.

Peterson Institute for International Economics. (2012). Policy Brief by Peter A. Petri, and Michael G. Plummer. The Trans-Pacific Partnership and Asia-Pacific Integration: Policy Implications. Johns Hopkins University and East-West Center, June 2012.

Raza, W., Grumiller, J, Taylor, L., Tröster, B., von Arnim, R. (2014). Assess TTIP: Assessing the Claimed Benefits of the Transatlantic Trade and Investment Partnership. Vienna: Austrian Foundation for Development Research.

Taylor, L., and R. von Arnim. (2006). Computable General Equilibrium Models of Trade Liberalization: The Doha Debate, New School for Social Research. Oxford: Oxfam GB.

World Bank (2018). Economic and Distributional Impacts of Comprehensive and Progressive Agreement for Trans-Pacific Partnership: The case of Vietnam. Washington, D.C: World Bank Group. 


\section{Appendix}

Table A.1 Malaysia's Exports and Imports at the Product-Level to CPTPP Countries and their Share in Malaysia's Global Exports and Imports in 2017

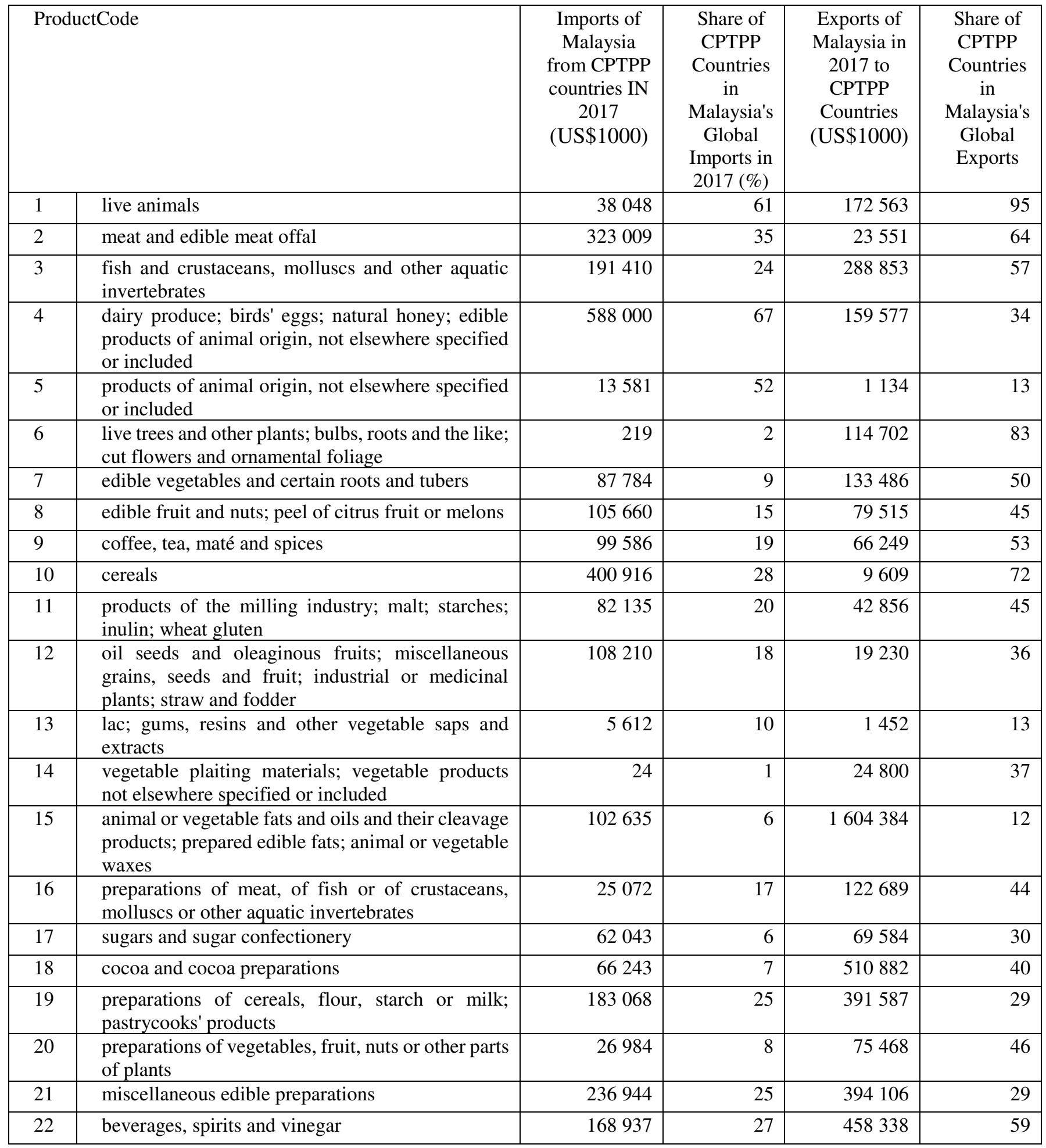




\begin{tabular}{|c|c|c|c|c|c|}
\hline 23 & $\begin{array}{l}\text { residues and waste from the food industries; } \\
\text { prepared animal fodder }\end{array}$ & 123299 & 11 & 159634 & 37 \\
\hline 24 & tobacco and manufactured tobacco substitutes & 29994 & 12 & 78789 & 32 \\
\hline 25 & $\begin{array}{l}\text { salt; sulphur; earths and stone; plastering materials, } \\
\text { lime and cement }\end{array}$ & 82604 & 19 & 157726 & 48 \\
\hline 26 & ores, slag and ash & 391275 & 21 & 72332 & 5 \\
\hline 27 & $\begin{array}{l}\text { mineral fuels, mineral oils and products of their } \\
\text { distillation; bituminous substances; mineral waxes }\end{array}$ & 9002963 & 36 & 17063108 & 52 \\
\hline 28 & $\begin{array}{l}\text { inorganic chemicals; organic or inorganic } \\
\text { compounds of precious metals, of rare-earth } \\
\text { metals, of radioactive elements or of isotopes }\end{array}$ & 847739 & 37 & 249868 & 29 \\
\hline 29 & organic chemicals & 936875 & 26 & 734775 & 19 \\
\hline 30 & pharmaceutical products & 155371 & 12 & 107151 & 46 \\
\hline 31 & fertilisers & 250619 & 25 & 192812 & 34 \\
\hline 32 & $\begin{array}{l}\text { tanning or dyeing extracts; tannins and their } \\
\text { derivatives; dyes, pigments and other colouring } \\
\text { matter; paints and varnishes; putty and other } \\
\text { mastics; inks }\end{array}$ & 277444 & 33 & 272222 & 40 \\
\hline 33 & $\begin{array}{l}\text { essential oils and resinoids; perfumery, cosmetic or } \\
\text { toilet preparations }\end{array}$ & 210055 & 21 & 133412 & 40 \\
\hline 34 & $\begin{array}{l}\text { soap, organic surface-active agents, washing } \\
\text { preparations, lubricating preparations, artificial } \\
\text { waxes, prepared waxes, polishing or scouring } \\
\text { preparations, candles and similar articles, } \\
\text { modelling pastes, 'dental waxes' and dental } \\
\text { preparation }\end{array}$ & 183855 & 30 & 171266 & 18 \\
\hline 35 & $\begin{array}{l}\text { albuminoidal substances; modified starches; glues; } \\
\text { enzymes }\end{array}$ & 58702 & 20 & 45819 & 26 \\
\hline 36 & $\begin{array}{lcc}\text { explosives; } & \text { pyrotechnic products; matches; } \\
\text { pyrophoric } \\
\text { alloys; certain combustible }\end{array}$ & 3495 & 16 & 3925 & 28 \\
\hline 37 & photographic or cinematographic goods & 45261 & 41 & 37162 & 19 \\
\hline 38 & miscellaneous chemical products & 462524 & 15 & 843582 & 20 \\
\hline 39 & plastics and articles thereof & 1903226 & 25 & 2402583 & 32 \\
\hline 40 & rubber and articles thereof & 556109 & 14 & 866224 & 12 \\
\hline 41 & $\begin{array}{l}\text { raw hides and skins (other than furskins) and } \\
\text { leather }\end{array}$ & 4476 & 5 & 4774 & 18 \\
\hline 42 & $\begin{array}{l}\text { articles of leather; saddlery and harness; travel } \\
\text { goods, handbags and similar containers; articles of } \\
\text { animal gut (other than silkworm gut) }\end{array}$ & 51367 & 10 & 30420 & 48 \\
\hline 43 & furskins and artificial fur; manufactures thereof & 4311 & 11 & 3138 & 7 \\
\hline 44 & wood and articles of wood; wood charcoal & 136572 & 20 & 1147275 & 33 \\
\hline 45 & cork and articles of cork & 1775 & 64 & 8 & 3 \\
\hline 46 & $\begin{array}{l}\text { manufactures of straw, of esparto or of other } \\
\text { plaiting materials; basketware and wickerwork }\end{array}$ & 2319 & 30 & 665 & 49 \\
\hline 47 & $\begin{array}{l}\text { pulp of wood or of other fibrous cellulosic } \\
\text { material; recovered (waste and scrap) paper or } \\
\text { paperboard }\end{array}$ & 59538 & 32 & 565 & 26 \\
\hline 48 & $\begin{array}{l}\text { paper and paperboard; articles of paper pulp, of } \\
\text { paper or of paperboard }\end{array}$ & 348004 & 19 & 479009 & 52 \\
\hline
\end{tabular}




\begin{tabular}{|c|c|c|c|c|c|}
\hline 49 & $\begin{array}{l}\text { printed books, newspapers, pictures and other } \\
\text { products of the printing industry; manuscripts, } \\
\text { typescripts and plans }\end{array}$ & 34680 & 17 & 82203 & 25 \\
\hline 50 & silk & 35 & 0 & 481 & 5 \\
\hline 51 & $\begin{array}{l}\text { wool, fine or coarse animal hair; horsehair yarn } \\
\text { and woven fabric }\end{array}$ & 20594 & 73 & 4764 & 15 \\
\hline 52 & cotton & 84979 & 19 & 46419 & 18 \\
\hline 53 & $\begin{array}{l}\text { other vegetable textile fibres; paper yarn and } \\
\text { woven fabrics of paper yarn }\end{array}$ & 153 & 3 & 369 & 7 \\
\hline 54 & $\begin{array}{l}\text { man-made filaments; strip and the like of man- } \\
\text { made textile materials }\end{array}$ & 43365 & 10 & 67514 & 16 \\
\hline 55 & man-made staple fibres & 29812 & 19 & 84453 & 26 \\
\hline 56 & $\begin{array}{l}\text { wadding, felt and nonwovens; special yarns; twine, } \\
\text { cordage, ropes and cables and articles thereof }\end{array}$ & 22348 & 12 & 111046 & 45 \\
\hline 57 & carpets and other textile floor coverings & 2348 & 2 & 13247 & 74 \\
\hline 58 & $\begin{array}{l}\text { special woven fabrics; tufted textile fabrics; lace; } \\
\text { tapestries; trimmings; embroidery }\end{array}$ & 2943 & 6 & 4352 & 26 \\
\hline 59 & $\begin{array}{l}\text { impregnated, coated, covered or laminated textile } \\
\text { fabrics; textile articles of a kind suitable for } \\
\text { industrial use }\end{array}$ & 21158 & 12 & 17430 & 23 \\
\hline 60 & knitted or crocheted fabrics & 9382 & 7 & 28837 & 17 \\
\hline 61 & $\begin{array}{l}\text { articles of apparel and clothing accessories, knitted } \\
\text { or crocheted }\end{array}$ & 83899 & 9 & 241091 & 25 \\
\hline 62 & $\begin{array}{l}\text { articles of apparel and clothing accessories, not } \\
\text { knitted or crocheted }\end{array}$ & 73566 & 11 & 59223 & 17 \\
\hline 63 & $\begin{array}{l}\text { other made-up textile articles; sets; worn clothing } \\
\text { and worn textile articles; rags }\end{array}$ & 151375 & 32 & 44593 & 22 \\
\hline 64 & footwear, gaiters and the like; parts of such articles & 136932 & 22 & 61365 & 41 \\
\hline 65 & headgear and parts thereof & 3587 & 12 & 24830 & 64 \\
\hline 66 & $\begin{array}{l}\text { umbrellas, sun umbrellas, walking sticks, seat- } \\
\text { sticks, whips, riding-crops and parts thereof }\end{array}$ & 159 & 1 & 442 & 48 \\
\hline 67 & $\begin{array}{l}\text { prepared feathers and down and articles made of } \\
\text { feathers or of down; artificial flowers; articles of } \\
\text { human hair }\end{array}$ & 183 & 1 & 734 & 48 \\
\hline 68 & $\begin{array}{l}\text { articles of stone, plaster, cement, asbestos, mica or } \\
\text { similar materials }\end{array}$ & 43532 & 15 & 345385 & 75 \\
\hline 69 & ceramic products & 27099 & 8 & 102953 & 40 \\
\hline 70 & glass and glassware & 291702 & 33 & 249194 & 26 \\
\hline 71 & $\begin{array}{l}\text { natural or cultured pearls, precious or semi- } \\
\text { precious stones, precious metals, metals clad with } \\
\text { precious metal, and articles thereof; imitation } \\
\text { jewellery; coin }\end{array}$ & 1237241 & 28 & 893944 & 30 \\
\hline 72 & iron and steel & 1346723 & 26 & 460179 & 20 \\
\hline 73 & articles of iron or steel & 840071 & 28 & 1007867 & 49 \\
\hline 74 & copper and articles thereof & 1407777 & 41 & 477569 & 22 \\
\hline 75 & nickel and articles thereof & 190313 & 69 & 35232 & 6 \\
\hline 76 & aluminium and articles thereof & 407403 & 16 & 761388 & 24 \\
\hline 78 & lead and articles thereof & 16248 & 19 & 24987 & 11 \\
\hline 79 & zinc and articles thereof & 94221 & 22 & 74685 & 20 \\
\hline
\end{tabular}




\begin{tabular}{|c|c|c|c|c|c|}
\hline 80 & tin and articles thereof & 41715 & 22 & 110816 & 19 \\
\hline 81 & other base metals; cermets; articles thereof & 16113 & 23 & 11153 & 36 \\
\hline 82 & $\begin{array}{l}\text { tools, implements, cutlery, spoons and forks, of } \\
\text { base metal; parts thereof of base metal }\end{array}$ & 171527 & 35 & 74665 & 37 \\
\hline 83 & miscellaneous articles of base metal & 56889 & 13 & 132442 & 48 \\
\hline 84 & $\begin{array}{l}\text { nuclear reactors, boilers, machinery and } \\
\text { mechanical appliances; parts thereof }\end{array}$ & 4964204 & 22 & 6366778 & 27 \\
\hline 85 & $\begin{array}{l}\text { electrical machinery and equipment and parts } \\
\text { thereof; sound recorders and reproducers, } \\
\text { television image and sound recorders and } \\
\text { reproducers, and parts and accessories of such } \\
\text { articles }\end{array}$ & 13745453 & 25 & 20728599 & 30 \\
\hline 86 & $\begin{array}{l}\text { railway or tramway locomotives, rolling stock and } \\
\text { parts thereof; railway or tramway track fixtures } \\
\text { and fittings and parts thereof; mechanical } \\
\text { (including electromechanical) traffic signalling } \\
\text { equipment of all kinds }\end{array}$ & 19685 & 20 & 3260 & 5 \\
\hline 87 & $\begin{array}{l}\text { vehicles other than railway or tramway rolling } \\
\text { stock, and parts and accessories thereof }\end{array}$ & 1515998 & 28 & 299438 & 18 \\
\hline 88 & aircraft, spacecraft, and parts thereof & 194158 & 6 & 520819 & 26 \\
\hline 89 & ships, boats and floating structures & 52979 & 4 & 62126 & 25 \\
\hline 90 & $\begin{array}{l}\text { optical, photographic, cinematographic, } \\
\text { measuring, checking, precision, medical or } \\
\text { surgical instruments and apparatus; parts and } \\
\text { accessories thereof }\end{array}$ & 1535436 & 28 & 2039255 & 26 \\
\hline 91 & clocks and watches and parts thereof & 258561 & 47 & 187344 & 75 \\
\hline 92 & $\begin{array}{l}\text { musical instruments; parts and accessories of such } \\
\text { articles }\end{array}$ & 8466 & 14 & 33493 & 27 \\
\hline 93 & $\begin{array}{l}\text { arms and ammunition; parts and accessories } \\
\text { thereof }\end{array}$ & 121 & 1 & 58 & 1 \\
\hline 94 & $\begin{array}{l}\text { furniture; bedding, mattresses, mattress supports, } \\
\text { cushions and similar stuffed furnishings; lamps } \\
\text { and lighting fittings, not elsewhere specified or } \\
\text { included; illuminated signs, illuminated } \\
\text { nameplates and the like; prefabricated buildings }\end{array}$ & 115670 & 11 & 779333 & 30 \\
\hline 95 & $\begin{array}{l}\text { toys, games and sports requisites; parts and } \\
\text { accessories thereof }\end{array}$ & 98704 & 18 & 106328 & 30 \\
\hline 96 & miscellaneous manufactured articles & 79318 & 22 & 136590 & 38 \\
\hline \multirow[t]{2}{*}{97} & works of art, collectors' pieces and antiques & 643 & 4 & 718 & 26 \\
\hline & total/average & 48545358 & 21 & 66942848 & 33 \\
\hline
\end{tabular}

Source: Author's estimations based on SMART simulations, WITS 
Table A. 2 : Change in Malaysia's Imports post the CPTPP -Product-Wise

\begin{tabular}{|c|c|c|c|c|}
\hline Chapter & & \begin{tabular}{|l|} 
Imports \\
Before CPTPP \\
(US\$1000) \\
$(\mathbf{2 0 1 6 )}$
\end{tabular} & $\begin{array}{l}\text { Imports after } \\
\text { CPTPP } \\
(\mathrm{US} \$ 1000)\end{array}$ & $\begin{array}{l}\text { Change in Imports post } \\
\text { CPTPP } \\
\text { (US } \$ 1000)\end{array}$ \\
\hline 87 & $\begin{array}{l}\text { vehicles other than railway or tramway rolling } \\
\text { stock, and parts and accessories thereof }\end{array}$ & 1794805 & 2436822 & 642017 \\
\hline 39 & plastics and articles thereof & 1325380 & 1562165 & 236785 \\
\hline 84 & $\begin{array}{l}\text { nuclear reactors, boilers, machinery and } \\
\text { mechanical appliances; parts thereof }\end{array}$ & 1353111 & 1585407 & 232296 \\
\hline 85 & $\begin{array}{l}\text { electrical machinery and equipment and parts } \\
\text { thereof; sound recorders and reproducers, } \\
\text { television image and sound recorders and } \\
\text { reproducers, and parts and accessories of such } \\
\text { articles }\end{array}$ & 994438 & 1180381 & 185943 \\
\hline 72 & iron and steel & 918529 & 1097007 & 178478 \\
\hline 76 & aluminium and articles thereof & 260588 & 373546 & 112958 \\
\hline 71 & $\begin{array}{l}\text { natural or cultured pearls, precious or semi- } \\
\text { precious stones, precious metals, metals clad with } \\
\text { precious metal, and articles thereof; imitation } \\
\text { jewellery; coin }\end{array}$ & 443476 & 539632 & 96156 \\
\hline 40 & rubber and articles thereof & 328741 & 424852 & 96111 \\
\hline 73 & articles of iron or steel & 657981 & 749545 & 91564 \\
\hline 48 & $\begin{array}{l}\text { paper and paperboard; articles of paper pulp, of } \\
\text { paper or of paperboard }\end{array}$ & 309558 & 385994 & 76437 \\
\hline 70 & glass and glassware & 247616 & 304324 & 56709 \\
\hline 27 & $\begin{array}{l}\text { mineral fuels, mineral oils and products of their } \\
\text { distillation; bituminous substances; mineral waxes }\end{array}$ & 5560478 & 5613275 & 52797 \\
\hline 35 & $\begin{array}{l}\text { albuminoidal substances; modified starches; glues; } \\
\text { enzymes }\end{array}$ & 38742 & 81794 & 43052 \\
\hline 32 & $\begin{array}{l}\text { tanning or dyeing extracts; tannins and their } \\
\text { derivatives; dyes, pigments and other colouring } \\
\text { matter; paints and varnishes; putty and other } \\
\text { mastics; inks }\end{array}$ & 147642 & 189642 & 42001 \\
\hline 21 & miscellaneous edible preparations & 250262 & 291053 & 40791 \\
\hline 10 & Cereals & 92746 & 129397 & 36651 \\
\hline 28 & $\begin{array}{l}\text { inorganic chemicals; organic or inorganic } \\
\text { comnounds of nrecious metals of rare-earth }\end{array}$ & 66414 & 97758 & 31345 \\
\hline 44 & wood and articles of wood; wood charcoal & 50993 & 80434 & 29441 \\
\hline 38 & miscellaneous chemical products & 139007 & 162121 & 23113 \\
\hline 83 & miscellaneous articles of base metal & 53682 & 75281 & 21599 \\
\hline 69 & ceramic products & 26515 & 47526 & 21011 \\
\hline
\end{tabular}




\begin{tabular}{|c|c|c|c|c|}
\hline 96 & miscellaneous manufactured articles & 56965 & 74110 & 17145 \\
\hline 94 & $\begin{array}{l}\text { furniture; bedding, mattresses, mattress supports, } \\
\text { cushions and similar stuffed furnishings; lamps } \\
\text { and lighting fittings, not elsewhere specified or } \\
\text { included; illuminated signs, illuminated } \\
\text { nameplates and the like; prefabricated buildings }\end{array}$ & 66699 & 82692 & 15993 \\
\hline 74 & copper and articles thereof & 50445 & 64367 & 13922 \\
\hline 82 & $\begin{array}{l}\text { tools, implements, cutlery, spoons and forks, of } \\
\text { base metal; parts thereof of base metal }\end{array}$ & 155662 & 169474 & 13811 \\
\hline 18 & cocoa and cocoa preparations & 52634 & 65106 & 12472 \\
\hline 34 & $\begin{array}{l}\text { soap, organic surface-active agents, washing } \\
\text { preparations, lubricating preparations, artificial }\end{array}$ & 81653 & 93083 & 11430 \\
\hline 56 & $\begin{array}{l}\text { wadding, felt and nonwovens; special yarns; twine, } \\
\text { cordage, ropes and cables and articles thereof }\end{array}$ & 29611 & 40071 & 10460 \\
\hline 68 & $\begin{array}{l}\text { articles of stone, plaster, cement, asbestos, mica or } \\
\text { similar materials }\end{array}$ & 28595 & 38922 & 10327 \\
\hline 52 & Cotton & 56599 & 66199 & 9600 \\
\hline 81 & other base metals; cermets; articles thereof & 30128 & 38961 & 8833 \\
\hline 54 & $\begin{array}{l}\text { man-made filaments; strip and the like of man- } \\
\text { made textile materials }\end{array}$ & 35372 & 42783 & 7411 \\
\hline 19 & $\begin{array}{l}\text { preparations of cereals, flour, starch or milk; } \\
\text { pastrycooks' products }\end{array}$ & 105493 & 112774 & 7281 \\
\hline 63 & $\begin{array}{l}\text { other made-up textile articles; sets; worn clothing } \\
\text { and worn textile articles; rags }\end{array}$ & 23545 & 30163 & 6618 \\
\hline 80 & tin and articles thereof & 64355 & 70746 & 6391 \\
\hline 25 & $\begin{array}{l}\text { salt; sulphur; earths and stone; plastering materials, } \\
\text { lime and cement }\end{array}$ & 7082 & 11799 & 4717 \\
\hline 17 & sugars and sugar confectionery & 17822 & 22138 & 4316 \\
\hline 22 & beverages, spirits and vinegar & 9984 & 14263 & 4279 \\
\hline 95 & $\begin{array}{l}\text { toys, games and sports requisites; parts and } \\
\text { accessories thereof }\end{array}$ & 12915 & 17019 & 4104 \\
\hline 15 & $\begin{array}{l}\text { animal or vegetable fats and oils and their cleavage } \\
\text { products; prepared edible fats; animal or vegetable }\end{array}$ & 40656 & 43982 & 3326 \\
\hline 55 & man-made staple fibres & 20047 & 23192 & 3144 \\
\hline 90 & $\begin{array}{l}\text { optical, photographic, cinematographic, } \\
\text { measuring, checking, precision, medical or } \\
\text { surgical instruments and apparatus; parts and } \\
\text { accessories thereof }\end{array}$ & 23566 & 26481 & 2915 \\
\hline 60 & knitted or crocheted fabrics & 8744 & 11428 & 2684 \\
\hline 37 & photographic or cinematographic goods & 8976 & 11106 & 2130 \\
\hline
\end{tabular}




\begin{tabular}{|c|c|c|c|c|}
\hline 49 & $\begin{array}{l}\text { printed books, newspapers, pictures and other } \\
\text { products of the printing industry; manuscripts, } \\
\text { typescripts and plans }\end{array}$ & 8993 & 11028 & 2035 \\
\hline 20 & $\begin{array}{l}\text { preparations of vegetables, fruit, nuts or other parts } \\
\text { of plants }\end{array}$ & 22090 & 24122 & 2031 \\
\hline 30 & pharmaceutical products & 8000 & 9740 & 1740 \\
\hline 58 & $\begin{array}{l}\text { special woven fabrics; tufted textile fabrics; lace; } \\
\text { tapestries; trimmings; embroidery }\end{array}$ & 4467 & 5959 & 1491 \\
\hline 86 & $\begin{array}{l}\text { railway or tramway locomotives, rolling stock and } \\
\text { parts thereof; railway or tramway track fixtures } \\
\text { and fittings and parts thereof; mechanical } \\
\text { (including electromechanical) traffic signalling } \\
\text { equipment of all kinds }\end{array}$ & 9162 & 10580 & 1418 \\
\hline 89 & ships, boats and floating structures & 5524 & 6520 & 996 \\
\hline 59 & $\begin{array}{l}\text { impregnated, coated, covered or laminated textile } \\
\text { fabrics; textile articles of a kind suitable for } \\
\text { industrial use }\end{array}$ & 2044 & 2884 & 840 \\
\hline 29 & organic chemicals & 7746 & 8562 & 816 \\
\hline 79 & zinc and articles thereof & 4050 & 4847 & 796 \\
\hline 36 & $\begin{array}{l}\text { explosives; pyrotechnic products; matches; } \\
\text { pyrophoric alloys; certain combustible } \\
\text { preparations }\end{array}$ & 3492 & 4102 & 610 \\
\hline 92 & $\begin{array}{l}\text { musical instruments; parts and accessories of such } \\
\text { articles }\end{array}$ & 1749 & 2278 & 529 \\
\hline 57 & carpets and other textile floor coverings & 1568 & 2062 & 494 \\
\hline 46 & $\begin{array}{l}\text { manufactures of straw, of esparto or of other } \\
\text { plaiting materials; basketware and wickerwork }\end{array}$ & 843 & 1284 & 442 \\
\hline 78 & lead and articles thereof & 1070 & 1365 & 295 \\
\hline 16 & $\begin{array}{l}\text { preparations of meat, of fish or of crustaceans, } \\
\text { molluscs or other aquatic invertebrates }\end{array}$ & 6607 & 6880 & 273 \\
\hline 64 & footwear, gaiters and the like; parts of such articles & 125 & 344 & 218 \\
\hline 12 & $\begin{array}{l}\text { oil seeds and oleaginous fruits; miscellaneous } \\
\text { grains, seeds and fruit; industrial or medicinal } \\
\text { plants; straw and fodder }\end{array}$ & 2039 & 2231 & 192 \\
\hline 67 & $\begin{array}{l}\text { prepared feathers and down and articles made of } \\
\text { feathers or of down; artificial flowers; articles of } \\
\text { human hair }\end{array}$ & 372 & 494 & 122 \\
\hline 91 & clocks and watches and parts thereof & 314 & 436 & 122 \\
\hline 93 & $\begin{array}{l}\text { arms and ammunition; parts and accessories } \\
\text { thereof }\end{array}$ & 290 & 374 & 83 \\
\hline 66 & $\begin{array}{l}\text { umbrellas, sun umbrellas, walking sticks, seat- } \\
\text { sticks, whips, riding-crops and parts thereof }\end{array}$ & 179 & 262 & 83 \\
\hline
\end{tabular}




\begin{tabular}{|c|c|c|c|c|}
\hline 62 & $\begin{array}{l}\text { articles of apparel and clothing accessories, not } \\
\text { knitted or crocheted }\end{array}$ & 483 & 559 & 76 \\
\hline 61 & $\begin{array}{l}\text { articles of apparel and clothing accessories, knitted } \\
\text { or crocheted }\end{array}$ & 58 & 120 & 62 \\
\hline 88 & aircraft, spacecraft, and parts thereof & 106 & 153 & 47 \\
\hline 45 & cork and articles of cork & 137 & 172 & 35 \\
\hline 11 & $\begin{array}{l}\text { products of the milling industry; malt; starches; } \\
\text { inulin; wheat gluten }\end{array}$ & 125 & 138 & 13 \\
\hline 97 & works of art, collectors' pieces and antiques & 64 & 72 & 9 \\
\hline 31 & Fertilisers & 101 & 105 & 3 \\
\hline \multirow[t]{2}{*}{50} & Silk & 14 & 17 & 3 \\
\hline & Total & 16122309 & 18665339 & 2543030 \\
\hline
\end{tabular}

Source: Author's estimations based on SMART simulations, WITS 
Table A. 3 : Change in Malaysia's Exports post the CPTPP -Product-Wise and Country Wise

\begin{tabular}{|c|c|c|c|c|c|c|}
\hline & $\begin{array}{l}\text { Product } \\
\text { Code }\end{array}$ & product description & $\begin{array}{l}\text { Exports } \\
\text { Before the } \\
\text { CPTPP } \\
\text { (US\$1000) }\end{array}$ & $\begin{array}{l}\text { Exports } \\
\text { After the } \\
\text { CPTPP } \\
\text { (US\$1000) }\end{array}$ & $\begin{array}{l}\text { Export } \\
\text { Change In } \\
\text { Revenue } \\
\text { post } \\
\text { CPTPP }\end{array}$ & $\begin{array}{l}\text { \% } \\
\text { Change }\end{array}$ \\
\hline Canada & 40 & rubber and articles thereof & 86078 & 96408 & 10329 & 12 \\
\hline Canada & 61 & $\begin{array}{l}\text { articles of apparel and clothing } \\
\text { accessories, knitted or crocheted }\end{array}$ & 16774 & 22477 & 5703 & 34 \\
\hline Canada & 94 & $\begin{array}{l}\text { furniture; bedding, mattresses, } \\
\text { mattress supports, cushions and } \\
\text { similar stuffed furnishings; lamps } \\
\text { and lighting fittings, not elsewhere } \\
\text { specified or included; illuminated } \\
\text { signs, illuminated nameplates and } \\
\text { the like; prefabricated buildings }\end{array}$ & 74531 & 79003 & 4472 & 6 \\
\hline Canada & 85 & $\begin{array}{l}\text { electrical machinery and equipment } \\
\text { and parts thereof; sound recorders } \\
\text { and reproducers, television image } \\
\text { and sound recorders and } \\
\text { reproducers, and parts and } \\
\text { accessories of such articles } \\
\end{array}$ & 218499 & 220684 & 2185 & 1 \\
\hline Canada & 62 & $\begin{array}{l}\text { articles of apparel and clothing } \\
\text { accessories, not knitted or } \\
\text { crocheted }\end{array}$ & 5059 & 6931 & 1872 & 37 \\
\hline Canada & 15 & $\begin{array}{l}\text { animal or vegetable fats and oils } \\
\text { and their cleavage products; } \\
\text { prepared edible fats; animal or } \\
\text { vegetable waxes }\end{array}$ & 17530 & 19108 & 1578 & 9 \\
\hline Chile & 85 & $\begin{array}{l}\text { electrical machinery and equipment } \\
\text { and parts thereof; sound recorders } \\
\text { and reproducers, television image } \\
\text { and sound recorders and } \\
\text { reproducers, and parts and }\end{array}$ & 30230 & 32346 & 2116 & 7 \\
\hline Chile & 40 & rubber and articles thereof & 24197 & 25649 & 1452 & 6 \\
\hline Chile & 15 & $\begin{array}{l}\text { animal or vegetable fats and oils } \\
\text { and their cleavage products; } \\
\text { prepared edible fats; animal or } \\
\text { vegetable waxes }\end{array}$ & 18807 & 19936 & 1128 & 6 \\
\hline Chile & 94 & $\begin{array}{l}\text { furniture; bedding, mattresses, } \\
\text { mattress supports, cushions and } \\
\text { similar stuffed furnishings; lamps } \\
\text { and lighting fittings, not elsewhere } \\
\text { specified or included; illuminated } \\
\text { signs, illuminated nameplates and } \\
\text { the like; prefabricated buildings }\end{array}$ & 19531 & 20508 & 977 & 5 \\
\hline
\end{tabular}




\begin{tabular}{|c|c|c|c|c|c|c|}
\hline Chile & 84 & $\begin{array}{l}\text { nuclear reactors, boilers, machinery } \\
\text { and mechanical appliances; parts } \\
\text { thereof }\end{array}$ & 9368 & 10117 & 749 & 8 \\
\hline Japan & 44 & $\begin{array}{l}\text { wood and articles of wood; wood } \\
\text { charcoal }\end{array}$ & 730589 & 752507 & 21918 & 3 \\
\hline Japan & 4 & $\begin{array}{l}\text { dairy produce; birds' eggs; natural } \\
\text { honey; edible products of animal } \\
\text { origin, not elsewhere specified or } \\
\text { included }\end{array}$ & 9350 & 26929 & 17579 & 188 \\
\hline Japan & 18 & cocoa and cocoa preparations & 159314 & 162500 & 3186 & 2 \\
\hline Japan & 19 & $\begin{array}{l}\text { preparations of cereals, flour, } \\
\text { starch or milk; pastrycooks' } \\
\text { products }\end{array}$ & 52782 & 57004 & 4223 & 8 \\
\hline Mexico & 85 & $\begin{array}{l}\text { electrical machinery and equipment } \\
\text { and parts thereof; sound recorders } \\
\text { and reproducers, television image } \\
\text { and sound recorders and } \\
\text { reproducers, and parts and }\end{array}$ & 1266394 & 1268261 & 1867.7 & 0.1 \\
\hline Mexico & 84 & $\begin{array}{l}\text { nuclear reactors, boilers, machinery } \\
\text { and mechanical appliances; parts } \\
\text { thereof }\end{array}$ & 239887 & 241066 & 1179.5 & 0.5 \\
\hline Mexico & 69 & ceramic products & 5426 & 7922 & 2496 & 46 \\
\hline Mexico & 44 & $\begin{array}{l}\text { wood and articles of wood; wood } \\
\text { charcoal }\end{array}$ & 29196 & 31531 & 2336 & 8 \\
\hline Mexico & 21 & miscellaneous edible preparations & 7950 & 9699 & 1749 & 22 \\
\hline Mexico & 40 & rubber and articles thereof & 31108 & 32664 & 1555 & 5 \\
\hline Mexico & 39 & plastics and articles thereof & 28529 & 29670 & 1141 & 4 \\
\hline Mexico & 34 & $\begin{array}{l}\text { soap, organic surface-active agents, } \\
\text { washing preparations, lubricating } \\
\text { preparations, artificial waxes, } \\
\text { prepared waxes, polishing or } \\
\text { scouring preparations, candles and } \\
\text { similar articles, modelling pastes, } \\
\text { 'dental waxes' and dental } \\
\end{array}$ & 8599 & 9631 & 1032 & 12 \\
\hline Mexico & 15 & $\begin{array}{l}\text { animal or vegetable fats and oils } \\
\text { and their cleavage products; } \\
\text { prepared edible fats; animal or } \\
\text { vegetable waxes }\end{array}$ & 8881 & 9947 & 1066 & 12 \\
\hline Peru & 85 & $\begin{array}{l}\text { electrical machinery and equipment } \\
\text { and parts thereof; sound recorders } \\
\text { and reproducers, television image } \\
\text { and sound recorders and } \\
\text { reproducers, and parts and }\end{array}$ & 29088 & 31124 & 2036 & 7 \\
\hline
\end{tabular}




\begin{tabular}{|l|c|l|r|r|r|r|} 
Peru & 40 & rubber and articles thereof & 14880 & 16071 & 1190 & 83 \\
\hline Vietnam & 24 & $\begin{array}{l}\text { tobacco and manufactured tobacco } \\
\text { substitutes }\end{array}$ & 18538 & 91765 & 73226 & 395 \\
\hline Vietnam & 55 & man-made staple fibres & 23933 & 31352 & 7419 & 31 \\
\hline Vietnam & 84 & $\begin{array}{l}\text { nuclear reactors, boilers, machinery } \\
\text { and mechanical appliances; parts } \\
\text { thereof }\end{array}$ & 523520 & 528755 & 5235 & 1 \\
\hline
\end{tabular}

Source: Author's estimations based on SMART simulations, WITS

Note: For estimating impact on exports, the exports figures of Malaysia are considered, which may be different from the import figures of the partner countries from Malaysia. Under Tobacco and manufactured tobacco substitutes, Malaysia's exports of HS 240220 (cigarettes containing tobacco) and HS240290 (other) increase.

\section{Table A.4: Total Tariff Revenue Loss to Malaysia Post CPTPP}

\begin{tabular}{|c|l|r|}
\hline & \multicolumn{1}{|c|}{$\begin{array}{c}\text { Total Tariff Revenue } \\
\text { Loss (US\$1000) }\end{array}$} \\
\hline & Total & $\mathbf{- 1 6 4 3 0 0 3}$ \\
\hline 87 & $\begin{array}{l}\text { vehicles other than railway or tramway rolling stock, and parts and } \\
\text { accessories thereof }\end{array}$ & -422413 \\
\hline 39 & plastics and articles thereof & -150164 \\
\hline 84 & $\begin{array}{l}\text { nuclear reactors, boilers, machinery and mechanical appliances; parts } \\
\text { thereof }\end{array}$ & -132047 \\
\hline 72 & iron and steel & -122065 \\
\hline 85 & $\begin{array}{l}\text { electrical machinery and equipment and parts thereof; sound recorders and } \\
\text { reproducers, television image and sound recorders and reproducers, and } \\
\text { parts and accessories of such articles }\end{array}$ & -113961 \\
\hline 40 & rubber and articles thereof & -82654 \\
\hline 76 & aluminium and articles thereof & -79676 \\
\hline 73 & articles of iron or steel & -68868 \\
\hline 10 & cereals & -49474 \\
\hline 48 & paper and paperboard; articles of paper pulp, of paper or of paperboard \\
\hline 71 & $\begin{array}{l}\text { natural or cultured pearls, precious or semi-precious stones, precious } \\
\text { metals, metals clad with precious metal, and articles thereof; imitation } \\
\text { jewellery; coin }\end{array}$ & -47839 \\
\hline 70 & glass and glassware & -44579 \\
\hline 32 & $\begin{array}{l}\text { tanning or dyeing extracts; tannins and their derivatives; dyes, pigments } \\
\text { and other colouring matter; paints and varnishes; putty and other mastics; } \\
\text { inks }\end{array}$ & -17594 \\
\hline 27 & $\begin{array}{l}\text { mineral fuels, mineral oils and products of their distillation; bituminous } \\
\text { substances; mineral waxes }\end{array}$ & -13884 \\
\hline 21 & miscellaneous edible preparations & -43342 \\
\hline 44 & wood and articles of wood; wood charcoal & -32950 \\
\hline 83 & miscellaneous articles of base metal & -24030 \\
\hline
\end{tabular}




\begin{tabular}{|c|c|c|}
\hline 38 & miscellaneous chemical products & -13403 \\
\hline 28 & $\begin{array}{l}\text { inorganic chemicals; organic or inorganic compounds of precious metals, } \\
\text { of rare-earth metals, of radioactive elements or of isotopes }\end{array}$ & -11940 \\
\hline 35 & albuminoidal substances; modified starches; glues; enzymes & -11516 \\
\hline 74 & copper and articles thereof & -9528 \\
\hline 96 & miscellaneous manufactured articles & -9323 \\
\hline 94 & $\begin{array}{l}\text { furniture; bedding, mattresses, mattress supports, cushions and similar } \\
\text { stuffed furnishings; lamps and lighting fittings, not elsewhere specified or } \\
\text { included; illuminated signs, illuminated nameplates and the like; } \\
\text { prefabricated buildings }\end{array}$ & -9262 \\
\hline 82 & $\begin{array}{l}\text { tools, implements, cutlery, spoons and forks, of base metal; parts thereof } \\
\text { of base metal }\end{array}$ & -8567 \\
\hline 34 & $\begin{array}{l}\text { soap, organic surface-active agents, washing preparations, lubricating } \\
\text { preparations, artificial waxes, prepared waxes, polishing or scouring } \\
\text { preparations, candles and similar articles, modelling pastes, 'dental } \\
\text { waxes' and dental preparation }\end{array}$ & -8328 \\
\hline 68 & articles of stone, plaster, cement, asbestos, mica or similar materials & -7575 \\
\hline 18 & cocoa and cocoa preparations & -7532 \\
\hline 69 & ceramic products & -7239 \\
\hline 56 & $\begin{array}{l}\text { wadding, felt and nonwovens; special yarns; twine, cordage, ropes and } \\
\text { cables and articles thereof }\end{array}$ & -6006 \\
\hline 52 & cotton & -6005 \\
\hline 20 & preparations of vegetables, fruit, nuts or other parts of plants & -5817 \\
\hline 63 & $\begin{array}{l}\text { other made-up textile articles; sets; worn clothing and worn textile } \\
\text { articles; rags }\end{array}$ & -4611 \\
\hline 81 & other base metals; cermets; articles thereof & -4431 \\
\hline 19 & preparations of cereals, flour, starch or milk; pastrycooks' products & -4091 \\
\hline 54 & man-made filaments; strip and the like of man-made textile materials & -3826 \\
\hline 80 & tin and articles thereof & -3538 \\
\hline 17 & sugars and sugar confectionery & -3063 \\
\hline 95 & toys, games and sports requisites; parts and accessories thereof & -2857 \\
\hline 25 & salt; sulphur; earths and stone; plastering materials, lime and cement & -2198 \\
\hline 22 & beverages, spirits and vinegar & -2152 \\
\hline 55 & man-made staple fibres & -2112 \\
\hline 15 & $\begin{array}{l}\text { animal or vegetable fats and oils and their cleavage products; prepared } \\
\text { edible fats; animal or vegetable waxes }\end{array}$ & -2087 \\
\hline 37 & photographic or cinematographic goods & -1683 \\
\hline 49 & $\begin{array}{l}\text { printed books, newspapers, pictures and other products of the printing } \\
\text { industry; manuscripts, typescripts and plans }\end{array}$ & -1601 \\
\hline 90 & $\begin{array}{l}\text { optical, photographic, cinematographic, measuring, checking, precision, } \\
\text { medical or surgical instruments and apparatus; parts and accessories } \\
\text { thereof }\end{array}$ & -1568 \\
\hline 60 & knitted or crocheted fabrics & -1531 \\
\hline 58 & $\begin{array}{l}\text { special woven fabrics; tufted textile fabrics; lace; tapestries; trimmings; } \\
\text { embroidery }\end{array}$ & -843 \\
\hline 89 & ships, boats and floating structures & -764 \\
\hline
\end{tabular}




\begin{tabular}{|c|c|c|}
\hline 79 & zinc and articles thereof & -600 \\
\hline 59 & $\begin{array}{l}\text { impregnated, coated, covered or laminated textile fabrics; textile articles } \\
\text { of a kind suitable for industrial use }\end{array}$ & -503 \\
\hline 86 & $\begin{array}{l}\text { railway or tramway locomotives, rolling stock and parts thereof; railway } \\
\text { or tramway track fixtures and fittings and parts thereof; mechanical } \\
\text { (including electromechanical) traffic signalling equipment of all kinds }\end{array}$ & -489 \\
\hline 29 & organic chemicals & -392 \\
\hline 30 & pharmaceutical products & -352 \\
\hline 92 & musical instruments; parts and accessories of such articles & -307 \\
\hline 36 & $\begin{array}{l}\text { explosives; pyrotechnic products; matches; pyrophoric alloys; certain } \\
\text { combustible preparations }\end{array}$ & -301 \\
\hline 46 & $\begin{array}{l}\text { manufactures of straw, of esparto or of other plaiting materials; } \\
\text { basketware and wickerwork }\end{array}$ & -204 \\
\hline 57 & carpets and other textile floor coverings & -172 \\
\hline 78 & lead and articles thereof & -166 \\
\hline 16 & $\begin{array}{l}\text { preparations of meat, of fish or of crustaceans, molluscs or other aquatic } \\
\text { invertebrates }\end{array}$ & -130 \\
\hline 12 & $\begin{array}{l}\text { oil seeds and oleaginous fruits; miscellaneous grains, seeds and fruit; } \\
\text { industrial or medicinal plants; straw and fodder }\end{array}$ & -94 \\
\hline 62 & articles of apparel and clothing accessories, not knitted or crocheted & -80 \\
\hline 91 & clocks and watches and parts thereof & -68 \\
\hline 67 & $\begin{array}{l}\text { prepared feathers and down and articles made of feathers or of down; } \\
\text { artificial flowers; articles of human hair }\end{array}$ & -68 \\
\hline 66 & $\begin{array}{l}\text { umbrellas, sun umbrellas, walking sticks, seat-sticks, whips, riding-crops } \\
\text { and parts thereof }\end{array}$ & -44 \\
\hline 93 & arms and ammunition; parts and accessories thereof & -29 \\
\hline 64 & footwear, gaiters and the like; parts of such articles & -27 \\
\hline 45 & cork and articles of cork & -21 \\
\hline 88 & aircraft, spacecraft, and parts thereof & -19 \\
\hline 61 & articles of apparel and clothing accessories, knitted or crocheted & -10 \\
\hline 97 & works of art, collectors' pieces and antiques & -3 \\
\hline 11 & products of the milling industry; malt; starches; inulin; wheat gluten & -2 \\
\hline 50 & silk & -2 \\
\hline 31 & fertilisers & -1 \\
\hline
\end{tabular}

Source: Author's estimations based on SMART simulations, WITS 